\title{
Biotechnological Addition of $\beta$-Glucans from Cereals, Mushrooms and Yeasts in Foods and Animal Feed
}

\author{
Viola Chiozzi ${ }^{1}$, Christos Eliopoulos ${ }^{2}$, Giorgos Markou ${ }^{2}$ (D), Dimitrios Arapoglou 2,*(D), Sofia Agriopoulou ${ }^{3}$ (D), \\ Hesham A. El Enshasy 4,5 iD and Theodoros Varzakas ${ }^{3, *(D)}$
}

1 Department of Chemistry, Materials and Chemical Engineering "Giulo Natta", Politechico di Milano, Piazza Leonardo da Vinci, 3220133 Milano, Italy; viola.chiozzi@mail.polimi.it

2 Institute of Technology of Agricultural Products, Hellenic Agricultural Organization—Demeter, L. Sof. Venizelou 1, 14123 Lykovrysi, Greece; chris_eliopoulos@hotmail.com (C.E.); markougior@gmail.com (G.M.)

3 Department of Food Science and Technology, University of the Peloponnese, 24100 Kalamata, Greece; s.agriopoulou@uop.gr

4 Institute of Bioproduct Development, Universiti Teknologi Malaysia, Johor Bahru 81310, Malaysia; henshasy@ibd.utm.my

5 City of Scientific Research and Technology Applications, New Bur Al Arab, Alexandria 21934, Egypt

* Correspondence: dimarap@yahoo.com (D.A.); t.varzakas@uop.gr (T.V.); Tel.: +30-210-284-5940 (D.A.)

check for updates

Citation: Chiozzi, V.; Eliopoulos, C.; Markou, G.; Arapoglou, D.; Agriopoulou, S.; El Enshasy, H.A.; Varzakas, T. Biotechnological Addition of $\beta$-Glucans from Cereals, Mushrooms and Yeasts in Foods and Animal Feed. Processes 2021, 9, 1889. https://doi.org/10.3390/pr9111889

Academic Editors: Tiane Finimundy, Taofiq Oludemi and Filipa S. Reis

Received: 24 September 2021

Accepted: 19 October 2021

Published: 22 October 2021

Publisher's Note: MDPI stays neutral with regard to jurisdictional claims in published maps and institutional affiliations.

Copyright: (c) 2021 by the authors. Licensee MDPI, Basel, Switzerland. This article is an open access article distributed under the terms and conditions of the Creative Commons Attribution (CC BY) license (https:// creativecommons.org/licenses/by/ $4.0 /)$.
Abstract: Varied cereal plants including, mushrooms, yeast, bacteria and algae are important sources of $\beta$-glucans, and many extraction procedures have been used in order to recover these valuable naturally occurring polysaccharides. The rheological and molecular properties of $\beta$-glucans can be utilized to be incorporated into various foods and to offer properties extremely beneficial to human health. Their functional effects are mainly determined by their molecular and structural characteristics. Consumption of foods fortified and enriched with $\beta$-glucans can contribute to the treatment of certain chronic diseases. Reduced cholesterol, cardiovascular and diabetic risk and moderate glycemic response of foods have been recorded with the consumption of these biologically active compounds. In addition, $\beta$-glucans are characterized by anti-cancer, antioxidant, anti-inflammatory and antiviral activities. As $\beta$-glucans interact with the foods in which they are incorporated, this review aims to discuss recent applications with quality and nutritional results of $\beta$-glucans incorporation with foods such as beverages, dairy, bakery, meat and pasta products, as well as their addition in animal feeds and their uses in other fields such as medicine.

Keywords: $\beta$-glucan; dietary fiber; fiber incorporation; nutritional quality; beneficial health effects; metabolic health parameters; cereals; mushrooms; nutritional quality; animal feed

\section{Introduction}

Human health is inextricably linked with food safety and nutrition which are considered as two of the most important factors. Food safety aims to the utilization of some natural ingredients derived from plants and animals, as nutraceuticals by hindering chronic diseases and promoting the good health and welfare. In order to overcome some chronic diseases, vast costs are required for treatments, so the development of non-invasive methods based on dietary and nutrition by consuming functional food ingredients is imperative. Functional are considered the foods which have the potential to provide with extra health benefits by encouraging and combating chronic diseases, but also to fulfil the basic human nutrients [1]. In the European countries, high blood pressure, smoking, overweight and obesity are considered as the most significant factors for a high number of deaths [2]. Several studies highlighted the importance of dietary fiber consumption, from whole grains or whole grain products by reducing the risk of some diseases such as cardiovascular disease, cancer and obesity occurrence. According to the European Union, dietary fibers are considered to be the carbohydrate polymers which are composed of three or more monometric units, which are not digested or absorbed by the human intestine [3]. Cereals such as oat 
and barley are known for their rich soluble fiber content and especially $\beta$-glucans. Cereals' and mushrooms' $\beta$-glucans form bioactive compounds which are found to exhibit various beneficial health effects. Cereal $\beta$-glucans are found on their cell walls whereas mushroom $\beta$-glucans are derived from their fruiting bodies.

$\beta$-Glucans are considered as dietary fibers and a complex of polysaccharides which are derived from various sources. $\beta$-Glucans' origin justifies the differences between structures, degrees of branching and branching patterns as well as molecular weights [4]. Based on their origin, $\beta$-glucans are grouped as cereal including oat and barley and non-cereal containing mushroom, algae, bacteria and seaweed $\beta$-glucans [5]. $\beta$-glucans are characterized as biologically active substances promoting health due to their physicochemical properties. Due to their beneficial effects, they have attracted interest for their exploitation in the food industry as potent means for reducing the risk or incidences of chronic diseases, encouraging lifespan as well as utilizing their anti-aging attributes. The nature of their beneficial effects is associated with their source and categorized as metabolic/GI or immune-modulatory effects [6,7]. Cereal $\beta$-glucans, which are composed of 1,3 and 1,4 linkages, usually exhibit metabolic effects, such as reduced cholesterol, cardiovascular and diabetic risk, as well as moderating the glycemic response of foods [8,9], whereas non cereal $\beta$-glucans are related with antitumor properties, not by attacking cancer cells directly but stimulating natural killer cells and macrophages (water-insoluble glucans from the edible fungus Ramaria botrytis) [10]. Additionally, they have shown anti-oxidant activity which is able to protect humans and animals by radiations [11,12], as well as immunomodulatory, immunostimulatory, anti-inflammation and antiviral activities against immune system disease properties [13-16]. These compounds have been used in the food industry for thickening and gelation purposes. For example, it has been observed that in beverages, $\beta$-glucans are supplemented in order to modify solution consistency, taking advantage of their thickening effect. Moreover, they are found in milk, bread and yogurt, thus contributing to cholesterol reduction, as well as decrease in energy intake [17]. $\beta$-Glucans besides food industry applications have also been used as additives in animal feed.

$\beta$-Glucans are considered to be the major components of plants' cell walls, especially in cereals (such as oat, barley and wheat), fungi, yeast mushrooms and algae but they are not present in human cells [17]. They are composed of D-glucose units linked by $\beta$-D-glycosidic bonds. $\beta$-Glucans in cereals are considered as linear homopolysaccharides composed of D-glucopyranosyl residues. Cereals' $\beta$ glucans are connected with a combination of 1,3 and 1,4 $\beta$-glycosidic bonds and present structural differences in the proportions of trimers to tetramers and $(1 \rightarrow 3)$-linkages to $(1 \rightarrow 4)$-bonds (Figure 1$)$ [2,4,18-21]. Cereals are considered as the most common $\beta$-glucans' source, rationalizing this by the fact that wheat has been found to contain $1 \% \beta$-glucans whereas oat and barley contain $3-7 \%$ and $5-11 \%$, respectively [17]. The structure of $\beta$-glucans is associated with their origination, exemplifying thus the differences between their physicochemical properties and beneficial effects. Based on their origin, $\beta$-glucans exhibit different physicochemical properties (shape, solubility, degree of branching) which affect their biological activities such as glucose reduction, serum cholesterol, obesity prevention immunomodulation and antitumor activity [2]. They are usually categorized to soluble and insoluble forms which are associated with the degree of polymerization (DP). $\beta$-Glucans with DP values over 100 , are considered as completely insoluble in water [22]. They have also a predominant role, especially in healthy foods and pharmaceutical products taking advantage of their beneficial properties such as antitumor activity, immunomodulation, glucose reduction and serum cholesterol as well as obesity prevention, hence they are equally used [17]. 


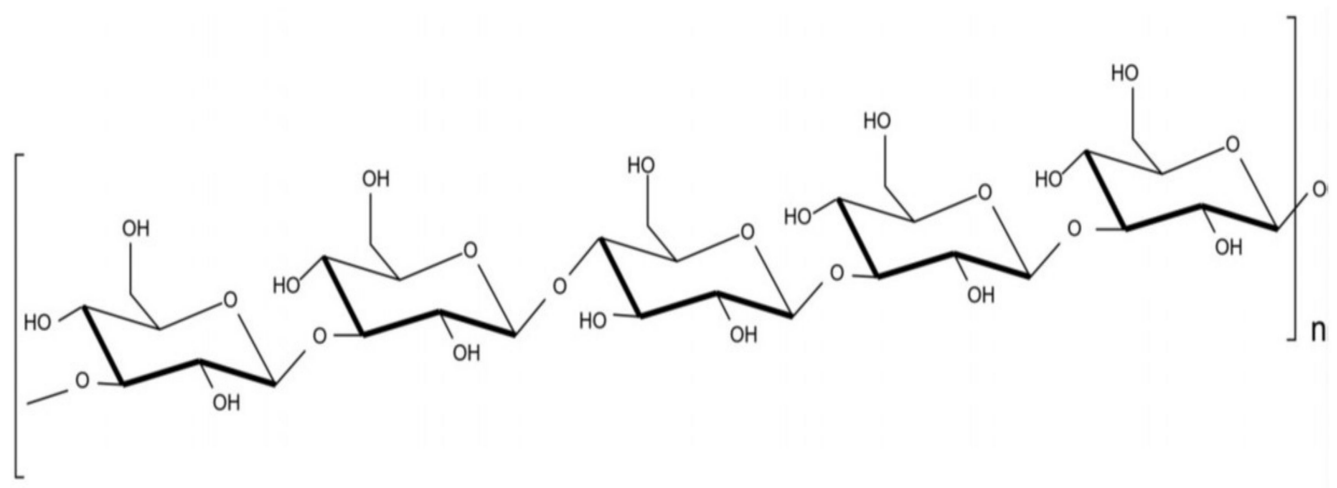

Figure 1. Structure of $(1 \rightarrow 3) \beta$-glucan linkages with $(1 \rightarrow 4)$ branches.

According to the European Food Safety Authority (EFSA) and the American Agency for Food and Drug Administration (FDA), a daily consumption of at least $3 \mathrm{~g}$ of barley or oat beta-glucans $(0.75 \mathrm{~g} /$ serving) have authorized several health claims, hence vast beneficial effects are connected with their consumption such as reduced blood pressure, decreased serum lipid content, lower blood glucose level, increased stool bulk, antitumor, immunomodulatory and immunostimulatory activities [23-25]. The health promoting effects of $\beta$-glucans are not limited only to the cholesterol adjustment but also on improved insulin resistance, obesity and the metabolic syndrome, however, the European Union legislation validates health claims concerning only the regulation of cholesterol and glucose reduction [26]. Microorganisms' $\beta$-glucans are composed of linear central backbone of glucose residues connected by $\beta-(1 \rightarrow 3)$ bonds and usually glucose side chains of different sizes are found to be connected by $\beta-(1 \rightarrow 6)$ linkages. Mainly, $\beta-(1 \rightarrow 6)$ change appears every two to three $\beta-(1 \rightarrow 3)$ main chain residues (Figure 2$)$. Despite the fact that $\beta$-glucans ${ }^{\prime}$ construction depends on their origin, they all are found to be right-handed triple helix structures, stabilized by interchain hydrogen bonds $[27,28]$. $\beta$-glucans derived from microorganisms usually exhibit some biological properties, whereas fungal $\beta$-glucans are described to have positive effects on diseases such as cancer, various microbial infections, hypercholesterolemia and diabetes [29].

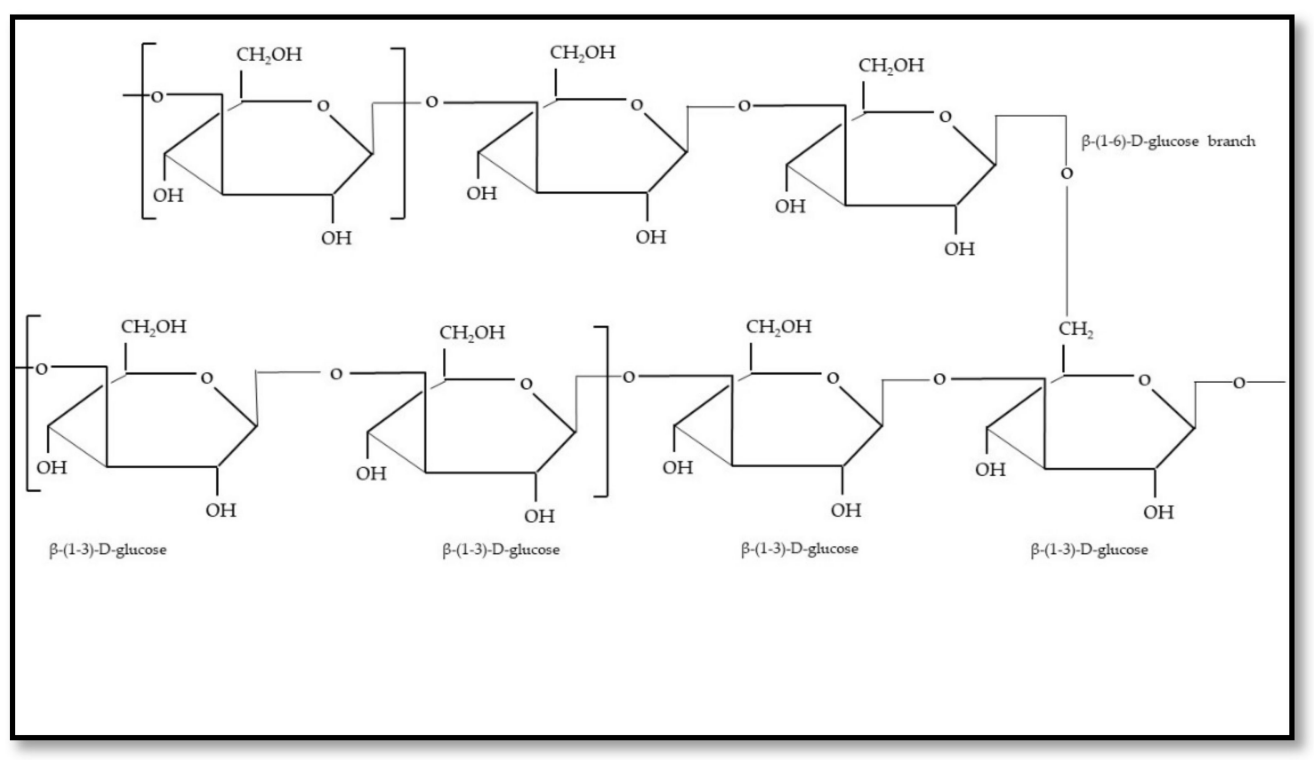

Figure 2. Structure of $\beta$-glucan molecules with $(1 \rightarrow 3)$ chains separated by $(1 \rightarrow 6)$ linkages.

Additionally, it must be noted that even though the edible mushrooms exceed 3000 species, 200 species have been experimented, 100 are produced on small scale, 60 have a potential 
commercial use and 10 are exploited on industrial scale [30]. The latter usually have a rapid cultivation and produce big quantities in short periods, providing a secure feedstock for a market that grow up continuously. Besides the use in the food and supplements (tablets/capsules) industry, $\beta$-glucans from mushrooms are exploited as feed supplement for chicken and fish. Indeed, it has been shown that this addition stimulates the animal's immune system, avoiding the large use of antibiotics [30]. Furthermore, $\beta$-glucans are widely used in the pharmaceutical industry as well as in the cosmetics sector taking advantage of their beneficial properties.

This review will describe the recent applications of the addition and incorporation of $\beta$-glucans derived from cereals, mushrooms and yeasts as additives in both food (dairy, meat, sweets and baked foods), beverages and animal feed.

\section{2. $\beta$-Glucans from Cereals}

\subsection{Extraction Methods of $\beta$-Glucans from Cereals}

The most common methods in order to isolate $\beta$-glucans are considered to be hot water extraction, alkali extraction, enzyme extraction, acidic extraction and other assisted extraction methods (ultrasound, microwave). Hot water extraction is employed to extract water-soluble $\beta$-glucans [17]. Grain sources are homogenized by milling in order to select the suitable samples' particle size. Prior to the extraction process, samples are refluxed with ethanol which contributes in enzymes' deactivation ( $\beta$-glucanase) and lipids' removal. Additionally, the optimum temperature is considered to be at 47 to $50{ }^{\circ} \mathrm{C}$ which hinders the solubility and subsequent gelatinization of starch [31]. Alkaline extraction has been used for the isolation of the water-insoluble $\beta$-glucans' fraction. Bhatty [32] extracted $\beta$-glucans of hull-less barley bran and two samples of commercial oat bran. The author stated that by using $\mathrm{NaOH}, 0.5 \mathrm{M} \beta$-glucans' extraction yield was the most efficient. Acidic extraction of $\beta$-glucans is a method that is not widely reported. Ahluwalia and Ellis [31,33] examined the isolation of $\beta$-glucans' content in barley. They used perchloric acid $(50 \mathrm{mM})$ for $\beta$-glucans' extraction. In order to evaluate $\beta$-glucans' content, the extract was hydrolyzed to glucose after sodium acetate buffer treatment and then was measured enzymatically. Extraction of $\beta$-glucan from barley using enzymatic method has been performed by Ahmed et al. [34]. More specifically, they performed a refluxing with ethanol to barley sample and subsequently, a treatment of $\alpha$-amylase and protease in order to extract and precipitate $\beta$-glucans. Babu et al. [35] also isolated $\beta$-glucans derived from whole oat flour applying the aforementioned method. The authors concluded that the yield of $\beta$-glucan on enzymatic extraction was the highest compared to alkaline and acidic extraction methods.

\subsection{Cereal $\beta$-Glucans as Food Additives}

$\beta$-glucans are widely used in the food industry sector due to their physicochemical properties. They are known as a functional food ingredient exhibiting beneficial effects in health especially by reducing serum cholesterol levels [36]. Besides their beneficial implications on health and nutrition, $\beta$-glucans have been found to exhibit different functional attributes such as thickening, stabilizing, emulsification and gelation justifying their presence very often to many products such as beverages, dairy, bakery, meat, pasta and other products [37]. Table 1 summarizes $\beta$-glucans' incorporation in various food products.

Table 1. $\beta$-Glucans' incorporation in various food products.

\begin{tabular}{|c|c|c|c|c|c|c|}
\hline Category & Type & Product & Concentration & Physiochemical Effects & Health Effects & Reference \\
\hline \multirow[t]{2}{*}{ Dairy products } & Oat $\beta$-glucan & $\begin{array}{l}\text { Fermented milk } \\
\text { products (kefir, yogurt } \\
\text { and fermented milk } \\
\text { beverages) }\end{array}$ & $0.6 \% w / w$ & $\begin{array}{l}\text { Oat } \beta \text {-glucan addition did } \\
\text { not affect the fermentation } \\
\text { time, modified sensory } \\
\text { properties and improved the } \\
\text { apparent viscosity }\end{array}$ & $\begin{array}{l}\text { Significant } \\
\text { reduction of total } \\
\text { and low lipoprotein } \\
\text { cholesterol }\end{array}$ & [38] \\
\hline & Oat $\beta$-glucan & Yogurt & $\begin{array}{c}0.1 \%, 0.15 \%, 0.20 \% \\
w / w\end{array}$ & $\begin{array}{c}\text { Improved sensory } \\
\text { characteristics, reduced } \\
\text { syneresis and better water } \\
\text { holding capacity }\end{array}$ & & [39] \\
\hline
\end{tabular}


Table 1. Cont.

\begin{tabular}{|c|c|c|c|c|c|c|}
\hline Category & Type & Product & Concentration & Physiochemical Effects & Health Effects & Reference \\
\hline & Barley $\beta$-glucan & Yogurt & $\begin{array}{c}(0.5,1,1.5, \text { and } 2 \% \\
w / w)\end{array}$ & $\begin{array}{l}\text { During storage: better whey } \\
\text { separation and viscosity, } \\
\text { enhanced texture profile and } \\
\text { sensory characteristics }\end{array}$ & & [40] \\
\hline & Oat $\beta$-glucan & Fermented milk & $1.4 \% w / w$ & $\begin{array}{c}\text { Separation between proteins } \\
\text { and incorporated } \\
\text { polysaccharide changing } \\
\text { gelation process }\end{array}$ & $\begin{array}{c}\text { Reduced blood } \\
\text { serum cholesterol } \\
\text { levels }\end{array}$ & [41] \\
\hline \multirow{7}{*}{ Bakery products } & Oat $\beta$-glucan & Dough & At least $2 \% w / w$ & $\begin{array}{l}\text { Increased } \beta \text {-glucan content } \\
\text { led to increased dough } \\
\text { stiffness as well as to reduced } \\
\text { dough extensibility }\end{array}$ & & [42] \\
\hline & Barley flour & Steamed bread & $10 \%-30 \% w / w$ & $\begin{array}{l}\text { Dough development, } \\
\text { departure and stability time } \\
\text { are reduced whereas the } \\
\text { mixing tolerance index } \\
\text { is increased }\end{array}$ & & [43] \\
\hline & $\begin{array}{l}\text { Barley flour } \\
\text { (enriched with } \\
\beta \text {-glucan) }\end{array}$ & Biscuits & $5.2 \% w / w$ & $\begin{array}{l}\text { Increased acceptability by } \\
\text { consumers. Sensory } \\
\text { responses were evaluated as } \\
\text { similar to the control }\end{array}$ & & [44] \\
\hline & Oat $\beta$-glucan & Steamed bread & $1 \%$ and $3 \% w / w$ & $\begin{array}{l}\text { Consumers' acceptance } \\
\text { was comparable }\end{array}$ & & [45] \\
\hline & Oat fiber powder & $\begin{array}{c}\text { Gluten-free } \\
\text { yeast-leavened cake }\end{array}$ & $5-20 \% w / w$ & $\begin{array}{l}\text { Improved springiness, } \\
\text { cohesiveness, porosity } \\
\text { and volume }\end{array}$ & & [46] \\
\hline & $\begin{array}{l}\text { Oat } \beta \text {-glucan } \\
\text { powder }\end{array}$ & $\begin{array}{c}\text { Gluten-free } \\
\text { yeast-leavened cake }\end{array}$ & $2.63 \% w / w$ & $\begin{array}{l}\text { Improved impacts on } \\
\text { volume, texture and } \\
\text { sensory acceptance }\end{array}$ & & {$[36,47]$} \\
\hline & Oat $\beta$-glucan & Bread & $\begin{array}{c}0.8 \%, 1 \% \text { and } 1.2 \% \\
w / w\end{array}$ & $\begin{array}{l}\text { No negative effects } \\
\text { concerning the } \\
\text { physicochemical and } \\
\text { sensory properties }\end{array}$ & $\begin{array}{l}\text { Glycemic index and } \\
\text { glycemic load were } \\
\text { found to be lower } \\
\text { compared to control }\end{array}$ & [48] \\
\hline \multirow{5}{*}{ Meat products } & $\begin{array}{l}\text { Oat } \beta \text {-glucan and } \\
\text { marine collagen } \\
\text { peptide mixed gel }\end{array}$ & $\begin{array}{l}\text { Low-fat sausage }(50 \% \\
\text { fat reduced) }\end{array}$ & Ratio 10:1 $(w / w)$ & $\begin{array}{l}\text { Increment of chewing and } \\
\text { springiness as well as taste } \\
\text { and palatability can be } \\
\text { compared with control }\end{array}$ & & {$[36,49]$} \\
\hline & $\begin{array}{l}\text { Cereal } \beta \text {-glucan } \\
\text { commercially }\end{array}$ & Beef emulsions & $3.13 \% w / w$ & $\begin{array}{c}\text { Higher } \beta \text {-glucans' content } \\
\text { showed less cooking loss and } \\
\text { improved cohesiveness, } \\
\text { hardness and } \\
\text { springiness values. }\end{array}$ & & {$[50]$} \\
\hline & Oat-soluble fibers & Beef patties & $13.45 \% w / w$ & $\begin{array}{l}\text { Optimum concentration in } \\
\text { order to be used as a fat } \\
\text { replacer in low-fat beef } \\
\text { patties maintaining though } \\
\text { fat and moisture. Improved } \\
\text { cooking yield }\end{array}$ & & {$[51]$} \\
\hline & Oat $\beta$-glucan & Fermented sausage & $0-2 \% w / w$ & $\begin{array}{l}\text { Addition of } \beta \text {-glucans did } \\
\text { not affect quality } \\
\text { characteristics of sausages }\end{array}$ & $\begin{array}{c}\text { Reduction of } \\
\text { reactive substances } \\
\text { of thiobarbituric acid }\end{array}$ & [52] \\
\hline & Oat $\beta$-glucan & Beef burgers & $\begin{array}{c}15 \% w / w(8 \%, 12 \%) \\
\text { and } 30 \% w / w \\
(4 \%, 6 \%)\end{array}$ & $\begin{array}{l}\text { Growth of water holding } \\
\text { capacity, } \mathrm{pH} \text { values, texture } \\
\text { parameters, as well as } \\
\text { improved sensory properties }\end{array}$ & Reduced cholesterol & [53] \\
\hline \multirow{4}{*}{ Pasta } & Oat $\beta$-glucan & Noodle & $10 \% w / w$ & $\begin{array}{l}\text { Increment of total dietary } \\
\text { fiber and essential minerals. } \\
\text { Reduction of glycemic index } \\
\text { and carbohydrate } \\
\text { digestibility rate }\end{array}$ & & [54] \\
\hline & $\begin{array}{c}\text { Oat } \beta \text {-glucan fiber } \\
\text { powder }\end{array}$ & Fresh pasta & $16 \% w / w$ & $\begin{array}{l}\text { Increased acceptability } \\
\text { by consumers }\end{array}$ & & [55] \\
\hline & Oat flour & Noodles & $10-30 \% w / w$ & $\begin{array}{l}\text { Noodles with } 10 \% \text { up to } 30 \% \\
\text { of oat flour exhibited a higher } \\
\beta \text {-glucan content as well as } \\
\text { firmness, while lightness, } \\
\text { color and stability } \\
\text { were reduced }\end{array}$ & & [56] \\
\hline & $\begin{array}{l}\text { Wholemeal oat } \\
\text { flour }\end{array}$ & Noodles & $>50 \% w / w$ & $\begin{array}{l}\text { Improved pasting viscosities } \\
\text { as well as noodle hardness }\end{array}$ & & [57] \\
\hline
\end{tabular}


Table 1. Cont.

\begin{tabular}{|c|c|c|c|c|c|c|}
\hline Category & Type & Product & Concentration & Physiochemical Effects & Health Effects & Reference \\
\hline Beverages & Oat $\beta$-glucan & Orange juice beverage & $0.5 \% w / v$ & $\begin{array}{c}\text { Factors of smoothness, } \\
\text { sweetness as well as } \\
\text { acceptance were found to be } \\
\text { like control. Improved } \\
\text { stability, reduced acidity after } \\
36 \text { h storage, changes in color, } \\
\text { increased viscosity }\end{array}$ & & [58] \\
\hline
\end{tabular}

\subsection{Dairy Products}

$\beta$-Glucans derived from oats and barley have been used for the enrichment of various dairy products such as milk, yogurt and kefir which have been studied concerning their physicochemical properties and potential health benefits. The effects of the addition of oat $\beta$-glucan to fermented milk products (kefir, yogurt and fermented milk beverages) have been examined in terms of their quality and health characteristics [38]. The addition of $0.6 \%$ oat $\beta$-glucan to all fermented milk products did not affect the fermentation time but the viscosity resulted in a significant increment. Cultured milk beverages displayed the highest sensory acceptance whereas yogurt beverage was the lowest. Fermented milk beverages are strongly recommended, because after their consumption, a significant alteration was revealed regarding total cholesterol, LDL-cholesterol and HDL-cholesterol [38]. Oat $\beta$-glucans have also been used for the preparation of functional yogurt with low-fat and non-fat contents. According to Aboushanab et al. [39], their presence displayed a significant improvement on sensory evaluation results, reduced syneresis, as well as the water capacity being enhanced. In low- and non-fat yogurt formulations, the viscosity recorded a significant increment whereas $\mathrm{pH}$ and titratable acidity were not affected. $\beta$-glucans also modified their viscoelastic behavior, intensifying its gel-like parameters. Concluding, the observed changes in rheological properties as well as the improved yogurt's yield resulted in the fat replacement. The addition of $0.10 \%$ and $0.20 \%$ displayed the best results for the low-fat and non-fat yogurt, respectively. The fortification of fermented milk with $1.4 \%$ of oat $\beta$-glucans led to a separation between proteins and the incorporated polysaccharide, changing thus the gelation process. This milk's enhancement was able to deplete the risk of heart diseases by reducing the blood serum cholesterol levels [41].

Barley's $\beta$-glucan supplementation in a full-fat yogurt was investigated regarding its sensory and chemical characteristics during storage. $\beta$-glucans' content incorporation, was applied in four different concentrations. The authors observed that during storage, $\beta$-glucans' addition improved viscosity, whey separation, texture profile and sensory characteristics. Furthermore, properties such as resilience, hardness and cohesiveness were found to be significantly improved. Additionally, the manufactured yogurt with $\beta$-glucan additions displayed higher consistency coefficient $(\mathrm{K})$, and a thicker and compact texture was observed. The higher $\beta$-glucans' concentration $(1.5-2 \%)$ resulted in the higher acceptability [40].

\subsection{Bakery Products}

Except from dairy products, oat and barley $\beta$-glucans have also been used in bakery products. Their addition has been performed as isolates, flour and powder. Londono et al. [42] examined the effects of oat $\beta$-glucans' content and viscosity on the technological properties of oat doughs for gluten-free and gluten-containing system. They revealed that the high $\beta$-glucan content depicts to a high dough stiffness but low dough extensibility. $\beta$-Glucans' behavior in dough systems is associated with the concentration and molecular weight, therefore, they concluded that a ratio of at least $2 \%$ was essential for improved baking quality. Additionally, $\beta$-glucans' addition showed negative impacts on the elastic properties that additional wheat gluten conferred to oat dough. Bread, which is considered as one of the most common bakery products, was also investigated. Specifically, steamed bread was prepared by replacing wheat flour with the addition of oat $\beta$-glucan at three 
different concentrations of $1 \%, 3 \%$ and $5 \%$. The additions of $1 \%$ and $3 \%$ did not impact on consumers' acceptance, unlike $5 \%$, which had negative effects on sensory quality, promoting thus the nutritional quality of steamed bread [45]. Another study revealed the health benefits of $\beta$-glucans' supplementation such as glycemic index (GI) and glycemic load. Mohebbi et al. [48] prepared white bread, enriched with oat $\beta$-glucans in three different concentrations $(0.8 \%, 1 \%$ and $1.2 \%)$. The incorporation of $1 \%$ displayed reduced GI, and glycemic load values were compared to the control. Additionally, $\beta$-glucans' enrichment did not have negative effects concerning the physicochemical and sensory properties. The physicochemical properties of a gluten-free yeast-leavened sweet cake were evaluated after its fortification with oat fiber powder, replacing rice or corn flour. Oat fiber powder additions, rich in $\beta$-glucans in high concentrations, form ideal alternatives for factors such as thickening and bulking for the preparation of a gluten-free cake. Additionally, the additions of $10 \%$ and $15 \%$ were optimum, hence porosity and volume were improved and firmness was maintained [46]. Moreover, it was revealed that oat $\beta$-glucans' presence at a ratio of $2.63 \%$ resulted not only in an increment of volume and lightness but in reduction of firmness and color difference. The manufactured gluten-free cake presented positive effects on texture and overall sensory quality. Under the aspect of health claims of oat $\beta$-glucans, the final product has the potential to be used as a functional alternative for common gluten-free products [47].

In some other studies bread, was also used for the evaluation of $\beta$-glucans derived from barley. Particularly, a steamed bread was manufactured by adding barley flour at three different concentrations ( $10 \%$ up to $30 \%$ ). The authors reported that after the addition of barley flour, the dough, departure and stability time were reduced with the mixing tolerance index showing an increment. Additionally, a rise in the content of barley flour reduced the specific volume, whiteness index and brightness of steamed bread, while hardness and chewiness were found to have increased [43].

Barley flour was used for the production of a new type of biscuits. Specifically, 100\% wheat flour was replaced with a mixture of $\beta$-glucan-enriched barley flour $(70 \%)$ and wheat flour (30\%). Incorporation of $5.2 \% \beta$-glucans from barley flour content was performed with the authors evaluating this addition, regarding appetite moods and food intake. The manufactured biscuits were found to be more acceptable by consumers, and their sensory responses were very close to the control. Furthermore, the consumption of these biscuits decreased the desire to eat hence the feeling of satiety was caused to the "subjects" [44].

\subsection{Meat Products}

The application of the enrichment with $\beta$-glucans has also been applied to meat products indicating its potential for fat replacement, as well as for their beneficial health properties.

Fan et al. [49] investigated the fat replacement in sausage products by incorporating oat $\beta$-glucan and marine collagen peptide mixed gel. A ratio of 10:1 was found to be the optimum combination between oat $\beta$-glucan and marine collagen peptide mixed gel for replacing fat by $50 \%$ in low-fat sausage. Springiness and chewing recorded a significant increase whereas taste and palatability could be compared to the control. Fermented sausage products containing different concentrations of beef fat and oat $\beta$-glucans, were manufactured in order to evaluate the effects of $\beta$-glucans' incorporation in terms of their physicochemical textural and sensorial properties, etc. It was observed that $\beta$-glucans' addition did not impact on quality parameters, such as fatty acids and physicochemical composition, and reduced the reactive substances of thiobarbituric acid [52]. $\beta$-Glucans were also used for the production of beef emulsion. Specifically, the supplementation by $3.13 \%$ of $\beta$-glucans in beef emulsion presented improved hardness, a homogeneous structure and normal thermal behavior which permits the preparation of such products containing high amounts of $\beta$-glucans by exhibiting desired functional properties. It must be mentioned that emulsions which contained higher amounts of $\beta$-glucans recorded less cooking loss and better hardness, cohesiveness and springiness values [50]. Oat 
$\beta$-glucans, were also investigated, in order to evaluate their impact on the physicochemical properties of low-fat beef patties. This study revealed that the addition of $13.45 \% \beta$-glucans increased the cooking yield while simultaneously maintained fat and moisture content. Finally, the manufactured low-fat beef patties showed to be less acceptable for taste but were significantly juicer than control, making oat fiber as a promising material for fat replacement in low-fat beef patties [51]. Oat $\beta$-glucan concentrates were investigated for their impact on the physicochemical properties of beef burgers as fat replacers. Specifically, two $\beta$-glucans with concentrates of $15 \%$ and $30 \%$ were isolated from oat grain, which were incorporated in four different ratios. Oat $\beta$-glucan concentrate of $15 \%$ was added at $8 \%$ and $12 \%$ in the manufactured burgers, whereas the oat $\beta$-glucan concentrate of $30 \%$ was supplemented at $4 \%$ and $6 \%$. It was found that beef tallow replacement by oat $\beta$-glucan resulted in an increment of water holding capacity and decreased cholesterol in the manufactured beef burger. Additionally, the fortification with oat $\beta$-glucans contributed to the rise of $\mathrm{pH}$ values. The use of $15 \%$ and $30 \%$ oat $\beta$-glucan concentrates led to an increment of texture parameters such as hardness, springiness, chewiness etc., and the profile of volatile compounds of low-fat beef burgers was observed to be altered. The authors concluded that the majority of sensory properties' acceptance was changed, except for color [53].

\subsection{Pasta Products}

Oat $\beta$-glucans were evaluated as food additives in pasta products. Choo and Aziz [54] prepared noodles by adding banana flour and oat $\beta$-glucans, for the determination of its nutritional and sensory attributes. They reported that the manufactured product exhibited higher total dietary fibers and essential minerals' content, with GI values as well as carbohydrate digestibility rate presenting a significant reduction. The effect of the addition of oat flour on white salted noodles at three different concentrations (10-30\%) regarding their quality characteristics was examined. It was observed that the increment of oat flour concentration led to higher protein, ash and firmness content. Furthermore, the incorporation of oat flour resulted in reduced lightness and color stability [56] whilst Nguyen et al. [57] revealed that the addition of wholemeal oat flour over $50 \%$ displayed increased hardness and pasting viscosities. The addition of oat fiber powder, rich in $\beta$-glucans on fresh pasta, was also investigated. The authors concluded that the concentration of $16 \%$ was the optimum. Specifically, according to the aforementioned $\beta$-glucans' incorporation, the consumers evaluated the manufactured pasta as more acceptable finding them more attractive. Moreover, it was shown that an increment of bran odor and flavor could lead to a higher perceived liking [55].

\subsection{Beverages}

Wan and $\mathrm{Xu}$ [58] added oat $\beta$-glucan and whey protein isolate to the orange juice beverage. They investigated the effects of this fortification as for the physicochemical properties. This study revealed that acceptance, smoothness and sweetness of the prepared beverage were quite similar to the control. After $36 \mathrm{~h}$ of storage, acidity was decreased. After $6 \mathrm{~h}$ of storage, color values recorded an increment while higher $\beta$-glucans' content improved viscosity values [58].

\section{Cereal $\beta$-Glucans' Additions in Animal Feed}

Besides $\beta$-glucans' exploitation in the food industry, they have also been used widely as animal feed (Table 2), utilizing thus their beneficial effects on animals' performance, health and welfare. Notwithstanding $\beta$-glucans' positive effects, a lot of studies revealed that their incorporation in poultry nutrition had adverse effects on performance and growth rate, so they are considered as antinutritional factors. Barley-based diets have a negative impact in growing birds, hence their consumption regarding birds' performance is considered as poor. High fiber content due to barley's hull was thought to be the major antinutritional factor, but several studies showed that barley varieties with less hull content 
led to similar results. Other studies showed that supplementation of isolated barley's $\beta$-glucan to a corn- based diet, led to a decreased performance, and viscosity was found to be increased by the collected samples [59]. Jha et al. [60] also reported that poultry nutrition based on fiber is not preferred due to their negative impact on low performance and nutrient utilization. The authors mentioned that some plant ingredients, such as cellulose and hemicellulose, cannot help poultry's gastrointestinal tract thus cannot be well digested. Moreover, the presence of arabinoxylans and pentosans in cereals result in a low nutritional value. Barley's high $\beta$-glucan concentration is responsible for its low nutritional value. Several studies with alfalfa revealed that its content of saponins had the potential to decrease egg production, reduce growth performance in mammals and birds, and hinder hypercholesterolemia. Pectin, which is a soluble fiber, augmented intestinal viscosity, and displayed negative effects on the young chick with low growth performance. The byproduct derived from raffinose's fermentation by microbial enzymes contributes in production of gases as well as diarrhea.

Table 2. Cereal $\beta$-glucans' incorporation in animal feed.

\begin{tabular}{|c|c|c|c|c|c|c|}
\hline Category & Type & Product & Concentration & $\begin{array}{c}\text { Physiochemical } \\
\text { Effects }\end{array}$ & Health Effects & Reference \\
\hline \multirow{4}{*}{ Animal Feed } & Oat $\beta$-glucan & Dog diet & $1 \% w / w$ & & $\begin{array}{l}\text { Total cholesterol } \\
\text { reduced, immune } \\
\text { response stimulated }\end{array}$ & {$[61]$} \\
\hline & Oat $\beta$-glucan & Pig diet & $8.95 \% w / w$ & & $\begin{array}{l}\text { Increased intestinal } \\
\text { bacterial populations, } \\
\text { regulated cytokine } \\
\text { production }\end{array}$ & {$[62]$} \\
\hline & Barley $\beta$-glucan & Growing pigs' diet & $1.54 \%, 1.80 \% w / w$ & & $\begin{array}{l}\text { Increased population } \\
\text { of beneficial bacteria }\end{array}$ & {$[63]$} \\
\hline & Barley $\beta$-glucan & Weanling pigs' diet & $\begin{array}{c}1.73 \%, 3.55 \% \\
7.37 \% w / w\end{array}$ & & $\begin{array}{l}\text { Increment of } \\
\text { intestinal barrier } \\
\text { permeability }\end{array}$ & {$[64]$} \\
\hline
\end{tabular}

Oat $\beta$-glucan's incorporation in dogs' diet has been investigated with regard to the nutritional, immunological metabolic and physiological effects in adult dogs. This study revealed that $1 \%$ supplementation of oat $\beta$-glucan had positive effects hence total cholesterol was reduced, and immune response was found to be stimulated. Furthermore, these findings are very promising, hence they are indicative of the potential use of oat $\beta$-glucan in order to feed obese animals [61]. Metzler-Zebeli et al. [62] evaluated the impact of oat $\beta$-glucans' addition combined with a diet composed of low- and high-phosphate content at a ratio of $8.95 \%$ in weaned pigs. They concluded that oat $\beta$-glucans increased intestinal bacterial populations including lactobacilli and bifidobacteria. Moreover, they reported that oat $\beta$-glucans' content is completely fermented in pigs' digestive tract thus upregulating cytokine production, as well as their large intestine function [63].

A diet consisting of low $(1.54 \%)$ and high $(1.80 \%) \beta$-glucan content in barley was offered to growing pigs. The authors reported that the presence of short chain fatty acids was notably increased. Barley's consumption with high $\beta$-glucans' concentration led to increased population of beneficial bacteria such as Lactobacillus with positive impact in piglets. Finally, they concluded that diets with high $\beta$-glucans' content resulted in reduced nutrient digestibility and animal performance, however, their use for a limited time after weaning has the potential to ameliorate their digestive health avoiding antibiotics $[64,65]$. The impact of barley-derived $\beta$-glucans' incorporation in weanling pigs' diet has also been investigated. More specifically, low-, medium- and high- $\beta$-glucan-containing barleybased diet containing $1.73 \%, 3.55 \%$ and $7.37 \% \beta$-glucans' content, respectively, was used. Authors stated that, in general, barley $\beta$-glucans contributed in the change of immune and intestinal activity by mostly raising CD4 cells and in the increment of intestinal barrier permeability, without negative impacts on animal growth and health. Regarding adult pigs' feed rich in $\beta$-glucans, ammonia emission and odors of feces were found to be 
decreased, while simultaneously, $\beta$-glucans contributed in augmented butyric acid levels in the intestine $[63,66]$.

\section{4. $\beta$-Glucans from Mushrooms}

\subsection{Extraction Methods of $\beta$-Glucans from Mushrooms}

$\beta$-Glucans' exploitation by the food and supplement market has attracted interest due to their therapeutic features. This fact has brought an increasingly intensive study on extraction methods, which permit to incorporate $\beta$-glucans in foods or tablets. Extracting these components from mushrooms, in some cases, can imply some problems due to the cell walls of the fungi and to the residues of pigments in the final extract. Commonly, the techniques used to obtain and fraction these important polysaccharides aim at destructing or weakening hydrogen bonds in mushrooms' cell walls by means of hot water, and, in some cases, followed by a severe alkaline treatment $[67,68]$. More in detail, considering the mushroom species cited in this review, we have hereby reported some examples of extraction methods used.

Yea-Woon Kim et al. [61] extracted $\beta$-glucans derived from Agaricus blazei by using hot water in thrice $\left(100{ }^{\circ} \mathrm{C}\right)$ for three hours, and then the extract was purified by a weak anion exchanger [69]. Hot water extraction is used also for Pleurotus ostreatus and Agaricus bisporus [70]. Their glucans are precipitated by addition of ethanol and then centrifuged and the sediment is dialyzed [71]. For the species of Pleurotus citrinopileatus, boiling water has been adopted after six days of percolation of the dried fruiting bodies with cold $\mathrm{EtOH}$ [72]. Water extraction at $4{ }^{\circ} \mathrm{C}$ followed by addition to excess of EtOH, filtration and centrifugation is used for Pleurotus florida. At the end, the precipitate is dialyzed to remove low-molecular weight material and freeze-dried [73].

Extraction with $\mathrm{NaOH}$ followed by centrifugation to separate hydrophobic part (glucan-containing hydrolysate) from the hydrophilic part (soluble heteroglycan extracts) of Ganoderma lucidum, has been performed by Kao et al. [65]; after separation step, the glucancontaining hydrolysate has been purified through gel-filtration chromatography [74]. Blafková et al. [14] have extracted $\beta$-glucans from Agaricus blazei, using $\mathrm{NaOH}$ solution at $90^{\circ} \mathrm{C}$ for two hours. Alkaline extraction is usually performed also for Lentinus edodes mushroom [75], as well as innovative technologies such as ultrasound-assisted extraction (UAE) or subcritical water extraction [76].

\subsection{Mushrooms' $\beta$-Glucans' Additions in Foods}

In the last decade, several research groups with the aim of understanding and improving the modifications of the biological and sensorial properties, as well as the shelf life, have examined $\beta$-glucans as food additives. Table 3 shows studies with mushrooms' $\beta$-glucans addition in foods.

Table 3. Studies with mushrooms' $\beta$-glucans' additions in foods.

\begin{tabular}{ccccc}
\hline Mushroom Species & Type of Food Enriched with $\beta$-Glucans & Properties & Extraction Method & Reference \\
\hline Agaricus bisporus & Sunflower oil & Improved oxidative stability & Hot water & [77] \\
\hline Agaricus blazei & Zootechnical food & $\begin{array}{c}\text { Beneficial effects on immune } \\
\text { system and gastrointestinal tract }\end{array}$ & Hot water & [78] \\
\hline Ganoderma lucidum & Cultured fish diet & Improved immune response & Alkaline & [79] \\
\hline Lentinus edodes & Yogurt & Natural supplements & Alkaline & {$[80]$} \\
& Extruded snacks & Decreasing of glycemic response & Fiber source & [83] \\
\hline Pleurotus agaves & Cultured fish diet & Immunostimulant activity & Hot water & [84] \\
\hline Pleurotus citrinopileatus & Flour and tortillas & Improved sensory quality & Hot water & [85] \\
\hline Pleurotus florida & Reduced fat yogurt & Improved flavor, texture and color & Hot water & [86] \\
\hline
\end{tabular}


Table 3. Cont.

\begin{tabular}{cccrc}
\hline Mushroom Species & Type of Food Enriched with $\beta$-Glucans & Properties & Extraction Method & Reference \\
\hline & Yogurt & Natural supplements & {$[80]$} \\
& Chicken patty & Fiber source & Hot water & {$[87]$} \\
Pleurotus ostreatus & Rextural improvements & {$[88]$} & {$[89]$} \\
& Commercial food & Probiotic source & Improved immune response & \\
\hline
\end{tabular}

Hozová et al. [80] combined white and fruit yogurts with two kinds of hydrogels of $\beta$-glucan, specifically pleuran from Pleurotus ostreatus and lentinan from Lentinus edodes. The analysis performed at 1st, 15th and 30th day of the storage showed an unchanged fermentation capability, $\mathrm{pH}$ and sensory suitability. In general, the yogurts with glucans do not vary considerably in the parameters evaluated and they do bring natural supplements to ordinary yogurts [80].

Brennan et al. [81] have analyzed the decrease in glycemic response of extruded snack products with an addition of mushroom $\beta$-glucan-rich fractions (Lentinus edodes). Adding $5 \%$ or $10 \%$ of mushroom material that replaces the wheat flour in the snack recipe, the total dietary fiber rises to 7.34 and $10.51 \%$, respectively, having a positive result on the texture of products, which is acceptable to customers, lowering product hardness and increasing the expansion. Furthermore, during the digestion time of starch, the total glucose detected is reduced to $18 \%$ and $25 \%$ for the $5 \%$ and $10 \%$ inclusion of mushroom material, respectively [81].

Going on a healthier way, Kim et al. [82] have incorporated powder of $\beta$-glucans from Lentinus edodes mushroom in foods and have studied them as a high-fiber and low-calorie flour substitute for baked foods. The mushroom powder was dispersed in distilled water and then filtrated. The residue was suspended in distilled water and autoclaved at $120{ }^{\circ} \mathrm{C}$ for $10 \mathrm{~min}$. The enriched cake batter presented increased viscosity, shear-thinning behaviors and elastic properties. At the same time, the food with higher contents of $\beta$-glucans has increased its hardness and reduced volume, while for the control sample and cake of $1 \mathrm{~g}$ of $\beta$-glucan per serving, there were no considerable differences. The quantity that makes a "heart-healthy" claim on food labels is $0.75 \mathrm{~g}$ of $\beta$-glucan per serving from oats and "a good source of fiber" if it contains $2.5 \mathrm{~g}$ or more of fiber. For these reasons, this study promotes mushrooms as a fiber enrichment source in commercial food processing [82,91].

A $3 \%$ enrichment with $\beta$-glucans in flours and tortillas from blue corn has been carried out by García-Rojas et al. [84] through an addition of Pleurotus agaves mushroom. The research focused on the effects on physicochemical and sensory properties of flours, doughs and tortillas made with traditional nixtamalization (TN) and ecological nixtamalization (EN). TN is a process that involves boiling the grain of corn with calcium hydroxide, therefore, in a strongly alkaline environment. Therefore, EN replaces $\mathrm{Ca}(\mathrm{OH})_{2}$ with $\mathrm{CaCl}_{2}$. The mushrooms have been dehydrated in drying oven to reach a moisture content of $10 \%$ and then sieved. The $9 \%$ of mushroom powder enriches the flour of the tortilla dough and brings some variation in properties. They have seen a strong rise in the antioxidant capacity but on the other side, the high process of nixtamalization and cooking temperatures reduced some compounds such as flavonoids, anthocyanins, vitamins, fats, proteins and dietary fiber. However, EN process, having lower $\mathrm{pH}$ than $\mathrm{TN}$, retains more nutrients. The sensory quality is guaranteed and improved by the addition of mushrooms combined with EN treatment. In conclusion, the tortillas produced with EN process associated with a 9\% content of Pleurotus agaves are the most similar to the $\mathrm{TN}-0 \%$ and represent a satisfactory and healthier alternative [84].

Considering dairy products, reduced fat yogurt with added $\beta$-glucans from Pleurotus citrinopileatus mushroom has been investigated by Pappa et al. [85]. Sensory properties, gel formation, microbial and physicochemical characteristics have been examined and compared to control yogurt (no addition of $\beta$-glucans) and added yogurt (with $\beta$-glucans) during 1, 7, 14 and 21 days of storage. The lyophilized powder of mushroom was treated 
with ethanol using a Soxhlet extractor for $8 \mathrm{~h}$. The residue of the mushroom was soaked in $0.9 \% \mathrm{NaCl}$ solution at $70{ }^{\circ} \mathrm{C}$ for $24 \mathrm{~h}$, centrifuged to remove the water-soluble polysaccharide, and the residue was extracted with $1 \mathrm{M} \mathrm{NaOH}$ at $40{ }^{\circ} \mathrm{C}$ for $8 \mathrm{~h}$. The percentages of $\beta$-glucans added were $0.0 \% w / w$ for the control, $0.3 \% w / w, 0.4 \% w / w$ and $0.5 \% w / w$ for the added yogurt. Protein content, $\mathrm{pH}$, fats and total solids did not differ with the sample at $0.3 \%$ concentration, whereas for the $0.5 \%$ sample, the lowest values for each parameters have been registered. Considering rheological properties, the viscosity decreases with the growing percentage of $\beta$-glucans. The microbial population was not affected by the different concentrations of the three samples for the entire storage period. Generally, the yogurts with $\beta$-glucans were the most appreciated, taking into account flavor, texture and appearance color [85]. $\beta$-Glucans, components of soluble or insoluble dietary fiber, have been included through Pleurotus sajor-caju, a variety of Pleurotus ostreatus mushroom, in a chicken patty by Wan Ishak et al. [87]. The group has focused on color, textural properties, cooking characteristics, fiber content and all the possible modifications related with the addition of $25 \%$ or $50 \%$ of fresh mushrooms in the recipe. What the $\beta$-glucans affect is the content of the total dietary fiber, which goes from a value of around $1.90 \mathrm{~g} / 100 \mathrm{~g}$ for a sample with no mushroom addition to $3.40 \mathrm{~g} / 100 \mathrm{~g}$ for a patty with $25 \%$ of addition and $4.90 \mathrm{~g} / 100 \mathrm{~g}$ with $50 \%$ of addition. All the other characteristics taken into consideration at a commercial level, such as color, hardness, water retention and chewiness did not compromise the potential appreciation by customers, in particular, in the case of $25 \%$ of mushroom fraction [87].

$\beta$-Glucans' textural properties' improvements have been observed by Kondyli et al. [88] who have analyzed the manufacture of reduced fat white-brined cheese with the addition of $0.4 \% \beta$-glucans from Pleurotus ostreatus. The lyophilized powder of mushroom was treated with ethanol using a Soxhlet extractor for $8 \mathrm{~h}$. The residue of the mushroom was soaked in $0.9 \% \mathrm{NaCl}$ solution at $70{ }^{\circ} \mathrm{C}$ for $24 \mathrm{~h}$, centrifuged to remove the watersoluble polysaccharide, and the residue was extracted with $1 \mathrm{M} \mathrm{NaOH}$ at $40{ }^{\circ} \mathrm{C}$ for $8 \mathrm{~h}$. Physicochemical properties such as $\mathrm{pH}$, moisture, moisture in non-fat substances, fat and fat in dry matter contents have been recorded during 180 days of ripening and storage, and no significant differences appeared between the cheeses made with or without the addition of $\beta$-glucans. Differently, the values of hardness and brittleness see an opposite trend until the period of 180 days, where they are almost the same. The hardness reduction gives a better effect in textural properties. Regarding color measurements, it has been noticed that the two analyzed cheeses present the same colors as well as the same organoleptic characteristics. The content of total free fatty acids varies only after 180 days of storage at which beta glucans added to cheese shows higher values; acetic and capric acid are the majority. Globally, $\beta$-glucans can be added to soften the cheese and to propose a healthier choice to the customers [88].

Aida et al. [89] have analyzed the literature discovering that probiotics such as inulin and oligosaccharides have been widely studied as functional food ingredients able to beneficially stimulate the growth and the activity of specific bacteria in the colon. In particular, humans cannot digest $\beta$-glucans' carbohydrates from mushrooms and hence, as it is a condition to be considered a probiotic, it enables mushrooms to be considered as a potential source of prebiotic. The study highlights the fact that incorporating mushroom extract in commercial foods could be an inexpensive and healthy choice since the material used is abundant. Moreover, it brings medicinal benefits such as prebiotic effects, in particular for Pleurotus ostreatus and Pleurotus eryngii, and also antitumor activities [89].

In food industry, microencapsulation is often used to guarantee a better stability of some products, in particular, protecting them from oxygen and humidity. Umaña et al. [77] investigated $\beta$-glucans derived from $A$. bisporus mushrooms as substitute for maltodextrin $\left(13.5 \% w / w\right.$ dry matter) and Tween ${ }^{\circledR} 20$ (totally substituted) in the sunflower oil microencapsulation process by spray drying. The mushrooms have been treated first with aqueous ethanol solution and then with acoustic energy for 20 minutes. Ergosterol have been added as an antioxidant agent. The encapsulation efficiency registered was 
of $89 \%$, and the samples with higher content of mushroom material rich in $\beta$-glucans showed an improved oxidative stability during microencapsulation process as well as a bigger diameter. Solubility in water was found to be decreased by $12 \%$ and linoleic acid recorded a reduction of $28 \%$ after 150 days of storage. Overall, the study reports mostly encouraging results that see polysaccharides from $A$. bisporus as possible replacement for synthetic emulsifiers [77].

\subsection{Mushrooms' $\beta$-Glucans' Additions in Animal Feed}

Freitas et al. [78] have evaluated changes in the immune system and the quality of eggs of hens, as well as general zootechnical performances, after the introduction of A. blazei mushroom flour into the animals' daily diet. The percentages of mushroom flour additions were $0 \%$ (control sample), $0.04 \%, 0.08 \%, 0.12 \%$ and $0.16 \%$. The parameters taken into consideration were the egg production rate, their weight and mass, along with the percentages of components, the yolks' color intensity and the shell thickness. No significant variations have been registered in general, but a level of $0.07 \%$ of mushrooms, adding substances like $\beta$-glucans, chitin, hemicellulose, galactans and xylans promoted beneficial effects on the immune system and on the gastrointestinal tract of the birds [78].

Edible mushrooms and their glucans' effects on animals have been studied also by Maiti et al. [86]. Their research focuses on the immunostimulant effects of $\beta$-glucans from Pleurotus florida, added in food feeding of Indian Major Carp. Glucan was isolated from the oyster mushroom by ethanol precipitation followed by cation and anion exchange chromatography. The concentrated polysaccharides were analyzed by gel permeation chromatography. The gel permeation produced three fractions. The one with the most polysaccharide, with a protein ratio of 24.6 was frozen at $-20^{\circ} \mathrm{C}$, lyophilized and stored in a desiccator. To determine the non-specific immune system response, intraperitoneal injection of Aeromonas hydrophila bacterium has been done at the end of two weeks of experimental feeding with glucans, then two weeks later ( 4 weeks of feeding) and, at last, after two other weeks (6 weeks of feeding). The quantity of glucans used is $0.5 \mathrm{~g}$ or $1 \mathrm{~g} / \mathrm{kg}$ of normal feed. For the former $(0.5 \mathrm{~g})$, an important superoxide anion production enhancement has been registered after two and four weeks; for the latter $(1 \mathrm{~g})$, just after four weeks. Phagocytosis activity has been noticed for both the concentrations after two and four weeks, and bactericidal activity after four and six weeks of glucan feeding. In both cases, the survival rate has increased substantially [86].

$\beta$-Glucans from Ganoderma lucidum and Coriolus versicolor mushrooms have been added in cultured, orange-sported grouper diet and by their effects being studied by Chang et al. [79]. Both the mushroom species were treated with homogenizer and ultrasonic vibration, and the residual carbohydrate molecules filtered using a ceramic membrane. They observed that adding $1 \mathrm{~g}$ and $2 \mathrm{~g}$ of a mixture containing $34.06 \%$ of $\beta$-glucans boosts the lysozyme activity, bursting respiration and the phagocytic activity of the fishes [79].

Moreover, rainbow trout (Oncorhynchus mykiss) have been analyzed for the splenic immune responses to bacterial lipopolysaccharide after their feeding with a supplement of lentinan, a $\beta$-glucan from mushroom Lentinus edodes. The immunostimulant response has been proved after 37 days of feeding with $0.2 \%$ and $0.4 \%$ of total nutrition, when fish were infected by the researcher with bacterial lipopolysaccharide that induces inflammation. In the control fishes group, the inflammatory response was higher in particular for interferon (IFN)-related and tumor necrosis factor (TNF)-dependent genes involved in Major Histocompatibility Complex (MHC) class I antigen presentation and leukocyte recruitment. Therefore, for markers of oxidative and cellular stress, a comparable trend has been registered [83].

Non-specific immune response has been checked also by Katya et al. [90] during their experiment with juvenile amur catfish, Silurus asotus. The fishes have been experimentally fed with fermented by-product of mushroom, Pleurotus ostreatus, rich in $\beta$-glucans. The mushroom by-product was fermented for $24 \mathrm{~h}$ at $30^{\circ} \mathrm{C}$ with Lactobacillus and yeast. The percentages of the mushroom by-products used were $0 \%, 5 \%, 10 \%, 20 \%$ and $30 \%$. The 
researchers have observed that the lysozyme activity was higher in fishes fed with $0 \%$ and $5 \%$ of experimental feeding, which was of $72.1 \mathrm{U} / \mathrm{mL}$ and $69.2 \mathrm{U} / \mathrm{mL}$, respectively. For $10 \%, 20 \%$ and $30 \%$ of experimental feeding, the values were $60.5 \mathrm{U} / \mathrm{mL}, 56.4 \mathrm{U} / \mathrm{mL}$ and $54.6 \mathrm{U} / \mathrm{mL}$, respectively [90].

Brewers' spent grain nutritional upgrade through solid state fermentation (SSF) was investigated in terms of its use as animal feed. It was found that by applying SSF process initiated by the edible fungi Pleurotus ostreatus, led to increased $\beta$-glucans' content, hence $P$. ostreatus constitutes a natural source of them. According to the results, all the examined nutritional characteristics were improved so authors indicated brewers' spent grain potential for use in animal feed [18].

\section{Yeast $\beta$-Glucans as Food Additives}

\subsection{Yeast $\beta$-Glucans as Food Additives}

Yeast $\beta$-glucans have been also used in the food industry in many conventional products by exploiting their beneficial properties such as flavor enhancing, etc. $\beta$-Glucans' presence in yeast forms an alternative protein source and are defined by 1,3 linkages branched by 1,6 $\beta$-glycosidic bonds [92].

The FDA characterized $\beta$-glucans from yeast as safe, by setting the daily intake up to $3 \mathrm{~g}$ /day [93]. EFSA attributed the safety claim of $\beta$-glucans in order to be incorporated as food additives at a ratio of 375 up to $600 \mathrm{mg} /$ day. The European Union Directive finalized the above claim by revising and concluding in 2019 that $\beta$-glucans derived from S. cerevisiae could be incorporated to other foods such as drinks $(1.3 \mathrm{~g} / \mathrm{kg})$, powdered milk $(25.5 \mathrm{~g} / \mathrm{kg})$, biscuits $(6.7 \mathrm{~g} / \mathrm{kg})$, cereals for breakfast $(15.3 \mathrm{~g} / \mathrm{kg})$ and up to $3.8 \mathrm{~g} / \mathrm{kg}$ in dairy products [92]. Yeast $\beta$-glucans addition in various foods is shown in Table 4.

Table 4. Yeast $\beta$-glucans' addition in various food products.

\begin{tabular}{|c|c|c|c|c|c|}
\hline Category & Type & Product & Concentration & Physiochemical Effects & Reference \\
\hline \multirow{11}{*}{ Food } & Yeast $\beta$-glucan & Bread & 65 up to $125 \mathrm{mg}$ & $\begin{array}{l}\text { Darkened crumb, enlarged crumb } \\
\text { and crust springiness impacted } \\
\text { on volatile profile and significant } \\
\text { increment on hexanal }\end{array}$ & [93] \\
\hline & $\begin{array}{l}\beta-\text { Glucans in brewers' } \\
\text { spent yeast }\end{array}$ & Bread & & Bread crust was browned & {$[94]$} \\
\hline & $\begin{array}{c}\text { Brewers' spent yeast } \\
\beta \text {-glucan }\end{array}$ & Bread & $\begin{array}{l}0.75 \% w / w \text { of wheat } \\
\text { flour }\end{array}$ & $\begin{array}{l}\text { Darkened the crumb, enlarged } \\
\text { augmented crumb and crust } \\
\text { springiness, increment of total } \\
\text { dietary fibers }\end{array}$ & [95] \\
\hline & Yeast $\beta$-glucan & Cookies & $2 \% w / w$ of wheat flour & $\begin{array}{l}\text { Sensorial attributes and } \\
\text { antioxidants upgraded }\end{array}$ & [96] \\
\hline & $\begin{array}{c}\text { Brewers' spent yeast } \\
\beta \text {-glucan }\end{array}$ & Yogurt & $0.3 \%, w / w$ & $\begin{array}{l}\text { Preserved sensory quality and } \\
\text { structure stability }\end{array}$ & [97] \\
\hline & $\begin{array}{c}\text { Brewers' spent yeast } \\
\beta \text {-glucan }\end{array}$ & Non-fat Yogurt & $1.5 \% w / w$ & $\begin{array}{l}\text { Physicochemical and rheological } \\
\text { properties were similar to the } \\
\text { full-fat yogurt }\end{array}$ & [98] \\
\hline & $\begin{array}{c}\text { Brewers' spent yeast } \\
\beta \text {-glucan }\end{array}$ & $\begin{array}{l}\text { Skimmed-milk } \\
\text { yogurt }\end{array}$ & $0.2-0.8 \% w / w$ & $\begin{array}{l}\text { Reduced the fermentation time, } \\
\text { textural properties increased }\end{array}$ & [99] \\
\hline & $\begin{array}{l}\beta \text {-glucans from } \\
\text { Saccharomyces } \\
\text { cerevisiae }\end{array}$ & $\begin{array}{l}\text { Skimmed-milk } \\
\text { yogurt }\end{array}$ & $0.5-1 \% w / w$ & $\begin{array}{l}\text { Yogurt firmness increased, } \\
\text { microstructure more stable }\end{array}$ & [7] \\
\hline & $\begin{array}{c}\text { Brewers' spent yeast } \\
\beta \text {-glucan }\end{array}$ & Mayonnaise & $25 \%, 50 \%$ and $75 \% w / w$ & $\begin{array}{c}\text { Negative impact at appearance } \\
\text { and color }\end{array}$ & [100] \\
\hline & $\begin{array}{c}\text { Brewers' spent yeast } \\
\beta \text {-glucan }\end{array}$ & Mayonnaise & $25 \%, 50 \%$ and $75 \% w / w$ & $\begin{array}{c}\text { Negative impact at appearance } \\
\text { and color }\end{array}$ & [101] \\
\hline & Yeast $\beta$-glucan & Meat products & $1.5-3 \% w / w$ & $\begin{array}{l}\text { Increased emulsifying capacity, } \\
\text { improved water holding capacity } \\
\text { and emulsion stability }\end{array}$ & {$[102]$} \\
\hline
\end{tabular}


Homemade bread was evaluated as for its physical parameters and sensorial characteristics after $\beta$-glucans' addition derived from yeast. This incorporation was performed by adding 65 up to $125 \mathrm{mg}$ of $\beta$-glucans, which was in line with EFSA's guidelines. $\beta$-Glucans' presence in bread darkened the crumb, enlarged crumb and crust springiness, impacted on volatile profile, and revealed a significant increment on hexanal without affecting sensory characteristics [94]. Martins et al. [95] prepared bread by adding $\beta$-glucans and proteins/proteolytic enzymes from brewers' spent yeast. Bread crust was browned, however, the addition of protein/proteolytic enzymes' extract resulted to lower specific volume whilst supplementation with $\beta$-glucans resulted to uniform pores. The nutritional upgrade was achieved after $\beta$-glucans' incorporation, resulting thus to a noteworthy increment of total dietary fibers. Wheat flour dough and bread were fortified with brewers' spent yeast $\beta$-glucan $(0.25-2.00 \%, w / w$ of wheat flour) in order to be examined as for their properties, during chilled storage at $4{ }^{\circ} \mathrm{C}$ for 8 days. Dough's fortification with $0.75 \%$ resulted in the highest levels concerning strength, work of adhesion and stickiness. Bread with $0.75 \%$ addition led to the lowest crumb hardness, chewiness and staling rate. Higher supplementations with $\beta$-glucans had adverse effects. Finally, incorporation of $0.75 \%$ displayed the overall acceptance after 4 storage days [96].

Cookies were examined in terms of their sensory attributes, oxidative stability, antioxidants and quality evaluation by adding yeast $\beta$-glucans. More specifically, wheat flour was substituted with $\beta$-glucans' isolates derived from yeasts by 1,2 and $4 \%$. It was observed that $2 \%$ fortification of $\beta$-glucans did not have a negative impact on cookies ${ }^{\prime}$ sensory acceptability but it could be interesting under consumers' aspect thus, sensorial attributes and antioxidants were upgraded. The manufactured cookies with high $\beta$-glucans' content displayed retardation in freshness losses as well as reduced glucose content. Finally, cookies' microbial load was insignificant whereas oxidative stability was enhanced [97].

$\beta$-Glucans from brewer's spent yeast were added to yogurt in order to investigate their impact concerning its structure, stability and sensory attributes. $\beta$-Glucans' supplementation affected yogurt's sensory and flavor characteristics such as thickness, smoothness, acid, bitter etc., as well as its structure stability. Specifically, it was reported that $\beta$-glucans addition up to $0.3 \%$ preserved sensory quality and structure stability [98]. Mejri et al. [99] also conducted a study using $\beta$-glucans' extracts, derived from spent brewer's yeast which were used at four proportions $(0,0.5,1$ and $1.5 \%)$ for the preparation of a non-fat yogurt. To the manufactured yogurt, $\beta$-glucans were incorporated as fat replacers following the aforementioned ratios in order to evaluate their physicochemical and rheological characteristics compared to control (full-fat yogurt). All the examined physicochemical and rheological values were found to be improved. Addition of $1.5 \%$ displayed the best results hence, its physicochemical and rheological properties were similar to the control. A skimmed-milk yogurt was fortified with powdered $\beta$-glucan isolate originated from brewer's spent yeast by $0.2-0.8 \% w / w$. The manufactured yogurt, was evaluated in the terms of its nutritional values, physicochemical and sensory characteristics. The authors stated that $\beta$-glucans' addition impacted on gel network formation, reducing thus the fermentation time. Physicochemical characteristics were not affected whereas textural properties displayed an incremental increase with parallel $\beta$-glucan increment. Additionally, this study indicated that $0.8 \% w / w$ of $\beta$-glucans' addition presented a negative effect at overall acceptance, however, the evaluation scores between the manufactured and control yogurt were not significant, displaying thus its potential for commercialization [100]. $\beta$-Glucans' isolates from Saccharomyces cerevisiae were extracted and used for the production of skimmed-milk yogurts. Specifically, $\beta$-glucans' extracts were added by $0.5 \%$ and $1 \%$ to the manufactured yogurt and were compared with full-fat and skimmed-milk yogurt as controls, in the terms or their physicochemical and sensory properties. By adding $0.5 \%$ $\beta$-glucans, skimmed-milk yogurt firmness was increased, as well as its microstructure was more stable. Additionally, the supplementation of $0.5 \%$ displayed lower values concerning sensory analysis, and despite the similar presented values to the control, the authors were discouraged by its commercialization [7]. 
Fat substitution by 25,50 and $75 \%$ with $\beta$-glucans from brewer's spent yeast was examined in mayonnaise. The results for the prepared mayonnaises displayed significant lower energy content but high water content, which was more intense as $\beta$-glucans' addition was increased. After one day of storage, $\mathrm{pH}$ values were not affected as compared to control, but after two months, $\mathrm{pH}$ values of the manufactured mayonnaises were found to be decreased. All the prepared mayonnaises were found to be microbiologically safe, hence their microbial load during storage was within acceptable limits. $\beta$-glucans' addition had a negative impact with regard to appearance and color, resulting in a significantly reduced sensory quality as compared to the control. Nevertheless, the authors stated that a maximum addition of $50 \%$ would be acceptable regarding the sensory attributes [101]. These findings are in accordance with Marinescu et al. [102] who also examined the application of using $\beta$-glucans as fat replacer, performing partial fat replacement in mayonnaise with $\beta$-glucans originating from brewer's spent yeast and following the same proportions.

Apostu et al. [103] investigated the addition of yeast $\beta$-glucans in meat products in order to reformulate them. Specifically, they incorporated yeast-derived ingredients consisting of $\beta$-glucans to meat batters and they found an increased emulsifying capacity, improved water holding capacity and emulsion stability. Yeast $\beta$-glucans' supplementation at a ratio of $1.5 \%$ led to total fluid reduction. Hardness and fracturability were also decreased whereas samples' structural cohesiveness was preserved, probably due to the growth of humidity. The authors also reported that the addition of $3 \%$ was considered as the highest proportion which did not affect meat batters' sensory characteristics. Yeast $\beta$-glucans' incorporation contributed to the upgrade of reformulated meat products' nutritional value and minimized cooking loss. Finally, the perceived saltiness without affecting sensory attributes was found to be increased.

\subsection{Yeast $\beta$-Glucans' Additions in Animal Feed}

Besides the incorporation of yeast $\beta$-glucans in food industry, they have been promoted for use in animal feed. Bacterial infections form a major factor for animals' health and productivity. Antibiotics are usually used in order to regulate these bacterial infections. Antibiotic residues are considered as their major drawback with many countries taking action by hindering their addition in animals' diets. $\beta$-Glucans have attracted interest considering their properties, hence they promote animal health and welfare as well as forming an ideal option for replacement of antibiotics [104]. Yeast $\beta$-glucans' addition in animal feed is depicted in Table 5.

Table 5. Yeast $\beta$-glucans' addition in animal feed.

\begin{tabular}{|c|c|c|c|c|c|c|}
\hline Category & Type & Product & Concentration & $\begin{array}{l}\text { Physiochemical } \\
\text { Effects }\end{array}$ & Health Effects & Reference \\
\hline \multirow{5}{*}{$\begin{array}{l}\text { Animal } \\
\text { Feeding }\end{array}$} & $\begin{array}{c}\beta \text {-glucan from } \\
\text { Agrobacterium sp. } \\
\text { R259 KCTC 10197B }\end{array}$ & Broiler chickens' diet & $\begin{array}{l}0.1 \% w / w \text { of } \\
\text { wheat flour }\end{array}$ & $\begin{array}{l}\text { Improved meat } \\
\text { quality in broiler } \\
\text { chickens }\end{array}$ & & [104] \\
\hline & $\begin{array}{l}\beta \text {-glucan from } \\
\text { Saccharomyces } \\
\text { cerevisiae }\end{array}$ & $\begin{array}{l}\text { Reared Haidong } \\
\text { chicks' diet }\end{array}$ & $\begin{array}{c}0.05 \%, 0.1 \% \text { and } \\
0.2 \% w / w\end{array}$ & & $\begin{array}{l}\text { Improved immune } \\
\text { parameters and } \\
\text { weight gain }\end{array}$ & [105] \\
\hline & $\begin{array}{l}\text { B-glucan from } \\
\text { Aureobasidium } \\
\text { pullulans }\end{array}$ & Broiler chickens' diet & $1 \% w / w$ & & $\begin{array}{l}\text { Improved immune } \\
\text { stimulating properties } \\
\text { and weight gain }\end{array}$ & [106] \\
\hline & $\begin{array}{c}\beta \text {-glucan from } \\
\text { Clostridium perfringens }\end{array}$ & Broiler chickens' diet & $200 \mathrm{mg} / \mathrm{kg}$ & & $\begin{array}{l}\text { Increment in body } \\
\text { weight and antibody } \\
\text { levels, improving gut } \\
\text { health }\end{array}$ & [107] \\
\hline & $\begin{array}{l}\beta \text {-glucan from } \\
\text { Saccharomyces } \\
\text { cerevisiae }\end{array}$ & $\begin{array}{l}\text { Ictalurus punctatus } \\
\text { juveniles' diet }\end{array}$ & $\begin{array}{c}0.05 \%, 0.1 \% \text { and } \\
0.5 \% w / w\end{array}$ & & $\begin{array}{l}\text { Improved immune } \\
\text { system }\end{array}$ & [108] \\
\hline
\end{tabular}


Table 5. Cont.

\begin{tabular}{|c|c|c|c|c|c|c|}
\hline Category & Type & Product & Concentration & $\begin{array}{c}\text { Physiochemical } \\
\text { Effects }\end{array}$ & Health Effects & Reference \\
\hline & $\begin{array}{c}\beta \text {-glucan from } \\
\text { Saccharomyces uvarum }\end{array}$ & Cyprinus carpios' diet & $1 \% w / w$ & & $\begin{array}{l}\text { Enhanced cellular and } \\
\text { humoral immune } \\
\text { response }\end{array}$ & [109] \\
\hline & $\begin{array}{l}\text { B-glucan from } \\
\text { Agrobacterium sp. } \\
\text { ZX09 }\end{array}$ & Pigs' diet & $100 \mathrm{mg} / \mathrm{kg}$ & & $\begin{array}{l}\text { Upgraded growth } \\
\text { performance, carcass } \\
\text { length, nutrient } \\
\text { digestibility }\end{array}$ & [110] \\
\hline & $\begin{array}{l}\beta \text {-glucan from } \\
\text { Saccharomyces } \\
\text { cerevisiae }\end{array}$ & Weaned pigs' diet & $200 \mathrm{mg} / \mathrm{kg}$ & & $\begin{array}{l}\text { Body weight gain, } \\
\text { reduced inflammation } \\
\text { response }\end{array}$ & {$[111]$} \\
\hline & $\begin{array}{l}\beta \text {-glucan from } \\
\text { Saccharomyces } \\
\text { cerevisiae }\end{array}$ & Rabbits' diet & $500 \mathrm{mg}$ & & $\begin{array}{c}\text { Enhanced antioxidant, } \\
\text { immunomodulatory } \\
\text { and } \\
\text { anti-inflammatory } \\
\text { profile against } \\
\text { pythiosis }\end{array}$ & {$[112]$} \\
\hline & $\begin{array}{l}\beta \text {-glucan from } \\
\text { Saccharomyces } \\
\text { cerevisiae }\end{array}$ & Ewes' diet & $3 \mathrm{~g} / \mathrm{kg}$ & $\begin{array}{c}\text { Higher milk } \\
\text { performance, proteins } \\
\text { and fat content }\end{array}$ & $\begin{array}{l}\text { Growth rate and } \\
\text { muscle tissue were } \\
\text { improved }\end{array}$ & {$[113]$} \\
\hline
\end{tabular}

The effects of $\beta$-glucans' addition derived from Agrobacterium sp. R259 KCTC 10197B on kefir was examined with regard to growth performance, blood profiles, relative organ weight and meat quality in broiler chickens. Specifically, 308 broilers were fed with five dietary treatments for 5 weeks. It was found that during $0-3$ weeks of the experiment, the dietary treatment which was incorporated with $0.1 \%$ of $\beta$-glucans, led to a higher body weight gain. Additionally, liver's relative weight displayed an increment, and cooking loss was decreased. Finally, the authors concluded that supplementation of broilers' dietary treatment with $0.1 \% \beta$-glucan contributes to growth performance and improves meat quality in broiler chickens [105]. Reared Haidong chicks were fed with diets fortified with $\beta$-glucans at different concentrations under hypoxic conditions, in order to evaluate growth performances, immunity and intestinal morphology effects. Diets were supplemented with $0.05 \%, 0.1 \%$ and $0.2 \% \beta$-glucans' isolates from S. cerevisiae. Body weight and body weight gain were found to be increased in chicks which were fed with $\beta$-glucan-fortified dietary treatments, as well as feed conversion displayed better results for the addition of 0.1 and $0.2 \%$. This study also revealed that the chosen immune parameters were improved by $0.1 \%$ and $0.2 \%$ of $\beta$-glucans' addition, a fact that promotes this inclusion in poultry diet for the reduction and replacement of antibiotics [106]. Rajapakse et al. [107] examined Shophy $\beta$-glucans' effects (a type of $\beta-1,3-1,6$ glucan produced by the black yeast Aureobasidium pullulans) on immunity and growth performance in broilers since they were exposed to Infectious Bursal Disease. It was found that birds' dietary supplementation with $1 \% \beta$ glucans showed significant increased body weight and mean antibody titers revealing $\beta$-glucans' immune stimulating properties. Another study evaluated broiler chickens' dietary supplementation with yeast $\beta$-glucans with regard to their effects in necrotic enteritis treatment caused by Clostridium perfringens. The authors found that after consumption of diet, incorporated with $200 \mathrm{mg} / \mathrm{kg}$ of $\beta$-glucans, the infected birds presented a significant increment in their body weight and antibody levels whereas feed efficiency was improved. $\beta$-Glucans' addition also exhibited their beneficial effects by improving gut health, hindering intestinal C. perfringens' growth and enhancing humoral immunity [108].

The impact of dietary supplementation with $\beta$-glucans originating from $S$. cerevisiae on immune response and hematology were evaluated at Ictalurus punctatus juveniles. $\beta$-Glucans were added at different concentrations of $0.05,0.1$ and $0.5 \%$ in the fishes' diet. The addition of $0.5 \%$ resulted into the best values concerning immunostimulation and hematological parameters. The authors concluded that the consumption of a diet supplemented with $0.5 \% \beta$-glucans improves the immune system [109]. Another study concerning 
$\beta$-glucans from Sacharomyces uvarum as well as whole cell yeast incorporation was conducted. $\beta$-Glucans were evaluated for their impact on Cyprinus carpio's immune response, concerning disease resistance to Aeromonas hydrophila by oral administration. The results revealed that by adding $1 \%$ of whole cell yeast and $\beta$-glucans in fishes' diet, $\beta$-glucans supplementation recorded the highest survival rate of the exposed fish to pathogen, hence they enhanced the cellular and humoral immune response in C. carpio [110].

Luo et al. [111] studied the supplementation of $\beta$-glucans in finishing pigs' diet for their effects in growth performance, carcass traits and meat quality. The experimental diets were fortified with 50,100 and $200 \mathrm{mg} / \mathrm{kg}$ of $\beta$-glucan from Agrobacterium sp. ZX09. The addition between 100 to $200 \mathrm{mg} / \mathrm{kg}$ showed a significant increment of carcass length while the addition of $100 \mathrm{mg} / \mathrm{kg}$ presented the best results. The supplementation of $100 \mathrm{mg} / \mathrm{kg}$ led to augmented daily gain feed conversion ratio and intramuscular fat content, and the ratio of saturated fatty acids and unsaturated fatty acids was found to altered. The authors concluded that the aforementioned supplementation of $100 \mathrm{mg} / \mathrm{kg}$ was able to upgrade growth performance, carcass length, nutrient digestibility and pork quality of finishing pigs. Evaluation of $\beta$-glucans' influence derived from S. cerevisiae in terms of growth performance and blood characteristics in weaned pigs, administered with Escherichia coli lipopolysaccharide, was also performed. Addition of $200 \mathrm{mg} / \mathrm{kg}$ indicated that $\beta$-glucans' incorporation in pigs' diet exhibited a positive impact according to body weight gain which was related with the reduced inflammation response after lipopolysaccharide (LPS) administration [112].

This study investigated $\beta$-glucans' impact from $S$. cerevisiae in rabbits' treatment, which were infected by Pythium insidiosum. Specifically, dietary consumption which was fortified with $500 \mathrm{mg}$ of $\beta$-glucans revealed their antioxidant, immunomodulatory and antiinflammatory profile against pythiosis, hence their presence was considered as a treatment adjuvant enhancing thus immunity and antioxidant attributes of the animals [113].

$\beta$-Glucans' isolates from S. cerevisiae were investigated regarding their effects on meat and milk performance, as well as on selected non-specific indicators of humoral and cellular defense. Ewes' diet fortified with $3 \mathrm{~g} / \mathrm{kg}$ of $\beta$-glucans resulted to higher milk performance, proteins and fat content while somatic cell count was reduced. Additionally, lambs' growth rate and muscle tissue were improved. Concerning results, $\beta$-glucans are encouraged for use, thus, their beneficial properties in animal feed were revealed without exceeding the ratio of $3 \mathrm{~g} / \mathrm{kg}$, avoiding thus, the implied risk of toxicity [114].

\section{Other $\beta$-Glucans' Applications}

Apart from $\beta$-glucans' exploitation in food and feed industry by reaping their nutritional and health beneficial effects, they have also been utilized by medicine and cosmetic industries. In the field of medicine, they have been used in vaccine applications, for dermatological treatments such as antiaging cures and for healing of eye ulcers [21,115]. Additionally, they have been found to have an impact on hypertension, obesity, Alzheimer's disease and pancreatitis, etc. [116]. Furthermore, the cosmetics sector used $\beta$-glucans in applications such as protective creams, ointments, powders, for treating eczema, etc. $\beta$-Glucans have been examined for their ability to decrease wrinkles and treat skin aging [21]. Mushrooms' $\beta$-glucans have been investigated for their contribution as exophthalmia's adjuvants. Several clinical trials have been conducted by utilizing $\beta$-glucans as wound dressing material taking advantage of their large inner cavity diameter. Finally, cereal $\beta$-glucans play a key role in the reduction of blood cholesterol sugar and insulin level, as well as in the reduced risk of cardiovascular diseases $[115,117]$.

\section{Conclusions}

Consumption of foods with $\beta$-glucans has been proven to contribute to human health with many beneficial properties. Their additional ability to act as thickeners, emulsifiers, and stabilizers makes them ideal additives in the dairy, confectionery, meat, pasta and bakery industries. Addition of $\beta$-glucan cereals to animal nutrition have also been studied by 
the scientific community with the results of research varying and in need of further investigation for each animal category and in each $\beta$-glucans' origin. In addition, their use has been extended to other fields such as cosmetics and medicine with quite promising results.

Author Contributions: Conceptualization, V.C., C.E., G.M., D.A., S.A., H.A.E.E. and T.V.; methodology, V.C., C.E., G.M., D.A., S.A., H.A.E.E. and T.V.; software, V.C., C.E., G.M., D.A., S.A., H.A.E.E. and T.V.; validation, V.C., C.E., G.M., D.A., S.A., H.A.E.E. and T.V.; formal analysis, V.C., C.E., G.M., D.A., S.A., H.A.E.E. and T.V.; investigation, V.C., C.E., G.M., D.A., S.A., H.A.E.E. and T.V.; resources, V.C., C.E., G.M., D.A., S.A., H.A.E.E. and T.V.; data curation, V.C., C.E., G.M., D.A., S.A., H.A.E.E. and T.V.; writing-original draft preparation, V.C., C.E., G.M., D.A., S.A., H.A.E.E. and T.V.; writing-review and editing, V.C., C.E., G.M., D.A., S.A., H.A.E.E. and T.V.; visualization, V.C., C.E., G.M., D.A., S.A., H.A.E.E. and T.V.; supervision, V.C., C.E., G.M., D.A., S.A., H.A.E.E. and T.V.; project administration, V.C., C.E., G.M., D.A., S.A., H.A.E.E. and T.V.; funding acquisition, V.C., C.E., G.M., D.A., S.A., H.A.E.E. and T.V. All authors have read and agreed to the published version of the manuscript.

Funding: This research received no external funding.

Institutional Review Board Statement: Not applicable.

Informed Consent Statement: Not applicable.

Data Availability Statement: Not applicable.

Conflicts of Interest: The authors declare no conflict of interest.

\section{References}

1. Din, A.; Chughtai, M.F.; Khan, M.R.; Shehzad, A.; Khaliq, A.; Nasir, M. Nutritional and Functional Perspectives of Barley ß-Glucan. Int. Food Res. J. 2018, 25, 1773-1784.

2. Ciecierska, A.; Drywień, M.; Hamulka, J.; Sadkowski, T. Nutraceutical Functions of Beta-Glucans in Human Nutrition. Rocz. Panstw. Zakl. Hig. 2019, 70, 315-324. [CrossRef]

3. Rezende, E.S.V.; Lima, G.C.; Naves, M.M.V. Dietary Fibers as Beneficial Microbiota Modulators: A Proposed Classification by Prebiotic Categories. Nutrition 2021, 89, 111217. [CrossRef]

4. Kremmyda, A.; MacNaughtan, W.; Arapoglou, D.; Eliopoulos, C.; Metafa, M.; Harding, S.E.; Israilides, C. The Detection, Purity and Structural Properties of Partially Soluble Mushroom and Cereal $\beta$-D-Glucans: A Solid-State NMR Study. Carbohydr. Polym. 2021, 266, 118103. [CrossRef]

5. Murphy, E.J.; Rezoagli, E.; Major, I.; Rowan, N.J.; Laffey, J.G. $\beta$-Glucan Metabolic and Immunomodulatory Properties and Potential for Clinical Application. J. Fungi 2020, 6, 356. [CrossRef]

6. Murphy, E.J.; Rezoagli, E.; Major, I.; Rowan, N.; Laffey, J.G. $\beta$-Glucans. Encyclopedia 2021, 1, 831. [CrossRef]

7. Santos, D.I.; Saraiva, J.; Vicente, A.; Moldão-Martins, M. Methods for determining bioavailability and bioaccessibility of bioactive compounds and nutrients. In Innovative Thermal and Non-Thermal Processing, Bioaccessibility and Bioavailability of Nutrients and Bioactive Compounds; Woodhead Publishing: Sawston, UK, 2019; pp. 23-54. ISBN 978-0-12-814174-8.

8. Wolever, T.M.S.; Gibbs, A.L.; Brand-Miller, J.; Duncan, A.M.; Hart, V.; Lamarche, B.; Tosh, S.M.; Duss, R. Bioactive Oat -Glucan Reduces LDL Cholesterol in Caucasians and Non-Caucasians. Nutr. J. 2011, 10, 10-13. [CrossRef] [PubMed]

9. Regand, A.; Chowdhury, Z.; Tosh, S.M.; Wolever, T.M.S.; Wood, P. The Molecular Weight, Solubility and Viscosity of Oat Beta-Glucan Affect Human Glycemic Response by Modifying Starch Digestibility. Food Chem. 2011, 129, 297-304. [CrossRef] [PubMed]

10. Bhanja, S.K.; Rout, D.; Patra, P.; Sen, I.K.; Nandan, C.K.; Islam, S.S. Water-Insoluble Glucans from the Edible Fungus Ramaria Botrytis. Bioact. Carbohydr. Diet. Fibre 2014, 3, 52-58. [CrossRef]

11. Pillai, T.G.; Maurya, D.K.; Salvi, V.P.; Janardhanan, K.K.; Nair, C.K.K. Fungal Beta Glucan Protects Radiation Induced DNA Damage in Human Lymphocytes. Ann. Transl. Med. 2014, 2, 1-7. [CrossRef]

12. Ceyhan, A.M.; Akkaya, V.B.; Güleçol, Ş.C.; Ceyhan, B.M.; Özgüner, F.; Chen, W.C. Protective Effects of $\beta$-Glucan against Oxidative Injury Induced by 2.45-GHz Electromagnetic Radiation in the Skin Tissue of Rats. Arch. Dermatol. Res. 2012, 304, 521-527. [CrossRef]

13. Zhang, P.; Cheung, P.C.K. Evaluation of Sulfated Lentinus Edodes $\alpha-(1 \rightarrow 3)$-d-Glucan as a Potential Antitumor Agent. Biosci. Biotechnol. Biochem. 2002, 66, 1052-1056. [CrossRef]

14. Blafková, P.; Synytsya, A.; Čopíková, J. Chitin-Glucan Complex from Agaricus Blazei, a Potential Raw Material for Production of Food Additives. Czech J. Food Sci. 2018, 22, 231-234. [CrossRef]

15. Rodrigues, M.V.; Zanuzzo, F.S.; Koch, J.F.A.; de Oliveira, C.A.F.; Sima, P.; Vetvicka, V. Development of Fish Immunity and the Role of $\beta$-Glucan in Immune Responses. Molecules 2020, 25, 5378. [CrossRef] [PubMed]

16. Byrne, K.A.; Loving, C.L.; McGill, J.L. Innate Immunomodulation in Food Animals: Evidence for Trained Immunity? Front. Immunol. 2020, 11, 1099. [CrossRef] [PubMed] 
17. Bai, J.; Ren, Y.; Li, Y.; Fan, M.; Qian, H.; Wang, L.; Wu, G.; Zhang, H.; Qi, X.; Xu, M.; et al. Physiological Functionalities and Mechanisms of $\beta$-Glucans. Trends Food Sci. Technol. 2019, 88, 57-66. [CrossRef]

18. Eliopoulos, C.; Arapoglou, D.; Chorianopoulos, N.; Markou, G.; Haroutounian, S.A. Conversion of Brewers' Spent Grain into Proteinaceous Animal Feed Using Solid State Fermentation. Environ. Sci. Pollut. Res. 2021. [CrossRef]

19. Lazaridou, A.; Biliaderis, C.G. Molecular Aspects of Cereal $\beta$-Glucan Functionality: Physical Properties, Technological Applications and Physiological Effects. J. Cereal Sci. 2007, 46, 101-118. [CrossRef]

20. Mejía, S.M.V.; de Francisco, A.; Bohrer, B. A Comprehensive Review on Cereal $\beta$-Glucan: Extraction, Characterization, Causes of Degradation, and Food Application. Crit. Rev. Food Sci. Nutr. 2020, 60, 3693-3704. [CrossRef]

21. Zhu, F.; Du, B.; Xu, B. A Critical Review on Production and Industrial Applications of Beta-Glucans. Food Hydrocoll. 2016, 52, 275-288. [CrossRef]

22. Du, B.; Bian, Z.; Xu, B. Skin Health Promotion Effects of Natural Beta-Glucan Derived from Cereals and Microorganisms: A Review. Phytother. Res. 2014, 28, 159-166. [CrossRef]

23. Schmidt, M. Cereal Beta-Glucans: An Underutilized Health Endorsing Food Ingredient. Crit. Rev. Food Sci. Nutr. 2020, 1-20. [CrossRef]

24. Carrieri, R.; Manco, R.; Sapio, D.; Iannaccone, M.; Fulgione, A.; Papaianni, M.; de Falco, B.; Grauso, L.; Tarantino, P.; Ianniello, F.; et al. Structural Data and Immunomodulatory Properties of a Water-Soluble Heteroglycan Extracted from the Mycelium of an Italian Isolate of Ganoderma Lucidum. Nat. Prod. Res. 2017, 31, 2119-2125. [CrossRef]

25. Wang, J.; Yuan, Y.; Yue, T. Immunostimulatory Activities of $\beta$-d-Glucan from Ganoderma Lucidum. Carbohydr. Polym. 2017, 102, 47-54. [CrossRef]

26. Commission Regulation (EU) No 432/2012 of 16 May 2012 Establishing a List of Permitted Health Claims Made on Foods, Other than Those Referring to the Reduction of Disease Risk and to Children's Development and Health. Available online: https:/ / eur-lex.europa.eu/LexUriServ/LexUriServ.do?uri=OJ:L:2012:136:0001:0040:en:PDF (accessed on 18 October 2021).

27. Brown, G.D.; Gordon, S. Immune Recognition of Fungal $\beta$-Glucans. Cell. Microbiol. 2005, 7, 471-479. [CrossRef]

28. Chihara, G. Immunopharmacology of Lentinan, a polysaccharide isolated from Lentinus edodes: Its application as a host defense potentiator. Int. J. Oriental Med. 1992, 17, 57-77.

29. Di Luzio, N.; Williams, D.; McNamee, R.; Edwards, B.; Kitahama, A. Comparative Tumor-inhibitory and Anti-bacterial Activity of Soluble and Particulate Glucan. Int. J. Cancer 1979, 24, 773-779. [CrossRef] [PubMed]

30. Cleanthes, I.; Eleftherios, E.; Vassilis, M. The Potential Use of Mushrooms $\beta$-Glucans in the Food Industry. Int. J. Biotechnol. Wellness Ind. 2014, 3, 15-18. [CrossRef]

31. Maheshwari, G.; Sowrirajan, S.; Joseph, B. Extraction and Isolation of $\beta$-Glucan from Grain Sources-A Review. J. Food Sci. 2017, 82, 1535-1545. [CrossRef]

32. Bhatty, R.S. Laboratory and Pilot Plant Extraction and Purification of $\beta$-Glucans from Hull-Less Barley and Oat Brans. J. Cereal Sci. 1995, 22, 163-170. [CrossRef]

33. Ahluwalia, B.; Ellis, E.E. A Rapid and Simple Method for the Determination of Starch and B-glucan in Barley and Malt. J. Inst. Brew. 1984, 90, 254-259. [CrossRef]

34. Ahmed, A.; Anjum, F.M.; Zahoor, T.; Nawaz, H.; Ahmed, Z. Extraction and Characterization of $\beta$-D-Glucan from Oat for Industrial Utilization. Int. J. Biol. Macromol. 2010, 46, 304-309. [CrossRef] [PubMed]

35. Babu, L. Green Extraction Techniques, Structural Analysis and Antioxidant Activites of $\beta$-Glucan Present in Oats. Intl. J. Latest Trends Eng. Technol. 2015, 5, 125-135.

36. Sun, L.; Hu, M.; Zhao, J.; Lv, L.; Zhang, Y.; Liu, Q.; Zhang, L.; Yu, C.; Wang, P.; Li, Q.; et al. Molecular Characteristics, Synthase, and Food Application of Cereal $\beta$-Glucan. J. Food Qual. 2021, 2021, 6682014. [CrossRef]

37. Ahmad, A.; Anjum, F.M.; Zahoor, T.; Nawaz, H.; Dilshad, S.M.R. Beta Glucan: A Valuable Functional Ingredient in Foods. Crit. Rev. Food Sci. Nutr. 2012, 52, 201-212. [CrossRef] [PubMed]

38. Liutkevičius, A.; Speiciene, V.; Alencikiene, G.; Aldona, M.; Kaminskas, A.; Abaravičius, J.; Vitkus, D.; Jablonskiene, V. Oat $\beta$-glucan in milk products: Impact on human health. J. Int. Sci. Publ. Agric. Food 2015, 3, 74-81.

39. Aboushanab, S.; Vyrova, D.; Selezneva, I. Characterization of Low- and Non-Fat Yogurt Manufactured with Addition of Beta-Glucanas as a Dietary Supplement. AIP Conf. Proc. 2018, 2015. [CrossRef]

40. Kaur, R.; Riar, C.S. Sensory, Rheological and Chemical Characteristics during Storage of Set Type Full Fat Yoghurt Fortified with Barley $\beta$-Glucan. J. Food Sci. Technol. 2020, 57, 41-51. [CrossRef] [PubMed]

41. Lazaridou, A.; Serafeimidou, A.; Biliaderis, C.G.; Moschakis, T.; Tzanetakis, N. Structure Development and Acidification Kinetics in Fermented Milk Containing Oat $\beta$-Glucan, a Yogurt Culture and a Probiotic Strain. Food Hydrocoll. 2014, 39, 204-214. [CrossRef]

42. Londono, D.M.; Gilissen, L.J.W.J.; Visser, R.G.F.; Smulders, M.J.M.; Hamer, R.J. Understanding the Role of Oat $\beta$-Glucan in Oat-Based Dough Systems. J. Cereal Sci. 2015, 62, 1-7. [CrossRef]

43. LIN, S.; Chen, H.-H.; Lu, S.; WANG, P. Effects of Blending of Wheat Flour with Barley Flour on Dough and Steamed Bread Properties. J. Texture Stud. 2012, 43, 438-444. [CrossRef]

44. Vitaglione, P.; Lumaga, R.; Montagnese, C.; Messia, M.C.; Marconi, E.; Scalfi, L. Satiating Effect of a Barley Beta-Glucan-Enriched Snack. J. Am. Coll. Nutr. 2010, 29, 113-121. [CrossRef] [PubMed]

45. Wang, L.; Ye, F.; Feng, L.; Wei, F.; Zhao, G. The Effects of Oat $\beta$-Glucan Incorporation on the Quality, Structure, Consumer Acceptance and Glycaemic Response of Steamed Bread. J. Texture Stud. 2017, 48, 562-570. [CrossRef] [PubMed] 
46. Karp, S.; Wyrwisz, J.; Kurek, M.; Wierzbicka, A. The Use of High-in- $\beta$-Glucan Oat Fibre Powder as a Structuring Agent in Gluten-Free Yeast-Leavened Cake. Food Sci. Technol. Int. 2019, 25, 108201321985678. [CrossRef] [PubMed]

47. Karp, S.; Wyrwisz, J.; Kurek, M.A. The Impact of Different Levels of Oat $\beta$-Glucan and Water on Gluten-Free Cake Rheology and Physicochemical Characterisation. J. Food Sci. Technol. 2020, 57, 3628-3638. [CrossRef] [PubMed]

48. Mohebbi, Z.; Azizi-lalabadi, M.; Hosseini, S.; Nowrouzani, S.; Mohammad-Alizadeh, S.; Homayouni, A. The Effects of Prebiotic Bread Containing Oat B-Glucan and Resistant Starch on the Glycemic Index and Glycemic Load in Healthy Individuals. Nutr. Food Sci. 2019, 49, 1029-1038. [CrossRef]

49. Fan, R.; Zhou, D.; Cao, X. Evaluation of Oat $\beta$-Glucan-Marine Collagen Peptide Mixed Gel and Its Application as the Fat Replacer in the Sausage Products. PLoS ONE 2020, 15, e0233447. [CrossRef] [PubMed]

50. Vasquez Mejia, S.M.; de Francisco, A.; Manique Barreto, P.L.; Damian, C.; Zibetti, A.W.; Mahecha, H.S.; Bohrer, B.M. Incorporation of $\beta$-Glucans in Meat Emulsions through an Optimal Mixture Modeling Systems. Meat Sci. 2018, 143, 210-218. [CrossRef] [PubMed]

51. Piñero, M.P.; Parra, K.; Huerta-Leidenz, N.; Arenas de Moreno, L.; Ferrer, M.; Araujo, S.; Barboza, Y. Effect of Oat's Soluble Fibre ( $\beta$-Glucan) as a Fat Replacer on Physical, Chemical, Microbiological and Sensory Properties of Low-Fat Beef Patties. Meat Sci. 2008, 80, 675-680. [CrossRef] [PubMed]

52. Yuca, B.; Topçu, I.; Yağcılar-Aydemir, H.; Özer, C.O.; Kılıç, B.; Başyiğit-Kılıç, G. Effects of Beta-Glucan Addition on the Physicochemical and Microbiological Characteristics of Fermented Sausage. J. Food Sci. Technol. 2019, 56, 3439-3448. [CrossRef] [PubMed]

53. Szpicer, A.; Onopiuk, A.; Półtorak, A.; Wierzbicka, A. The Influence of Oat $\beta$-Glucan Content on the Physicochemical and Sensory Properties of Low-Fat Beef Burgers. CyTA-J. Food 2020, 18, 315-327. [CrossRef]

54. Chong, C. Abdul aziz, noor aziah Effects of Banana Flour and $\beta$-Glucan on the Nutritional and Sensory Evaluation of Noodles. Food Chem. 2010, 119, 34-40. [CrossRef]

55. Jaworska, D.; Królak, M.; Przybylski, W.; Jezewska-Zychowicz, M. Acceptance of Fresh Pasta with $\beta$-Glucan Addition: Expected Versus Perceived Liking. Foods 2020, 9, 869. [CrossRef]

56. Mitra, S.; Cato, L.; James, A.; Solah, V. Evaluation of White Salted Noodles Enriched with Oat Flour. Cereal Chem. 2012, 89, 117-125. [CrossRef]

57. Nguyen, T.T.L.; Gilbert, R.G.; Gidley, M.J.; Fox, G.P. The Contribution of $\beta$-Glucan and Starch Fine Structure to Texture of Oat-Fortified Wheat Noodles. Food Chem. 2020, 324, 126858. [CrossRef]

58. Wan, W.; Xu, B. Development of an Orange Juice Beverage Formulated with Oat Beta-Glucan and Whey Protein Isolate: Development of an Orange Juice. J. Sci. Food Agric. 2018, 98, 4685-4691. [CrossRef]

59. Jacob, J.P.; Pescatore, A.J. Using Barley in Poultry Diets-A Review. J. Appl. Poult. Res. 2012, 21, 915-940. [CrossRef]

60. Jha, R.; Mishra, P. Dietary Fiber in Poultry Nutrition and Their Effects on Nutrient Utilization, Performance, Gut Health, and on the Environment: A Review. J. Anim. Sci. Biotechnol. 2021, 12, 51. [CrossRef] [PubMed]

61. Ferreira, L.; Endrighi, M.; Lisenko, K.; Oliveira, M.; Damasceno, M.; Claudino, J.; Gutierres, P.; Peconick, A.; Saad, F.; Zangeronimo, M. Oat Beta-Glucan as a Dietary Supplement for Dogs. PLoS ONE 2018, 13, e0201133. [CrossRef]

62. Metzler-Zebeli, B.; Zijlstra, R.; Mosenthin, R. Dietary Calcium Phosphate Content and Oat $\beta$-Glucan Influence Gastrointestinal Microbiota, Butyrate-Producing Bacteria and Butyrate Fermentation in Weaned Pigs. FEMS Microbiol. Ecol. 2011, 75, 402-413. [CrossRef] [PubMed]

63. Suchecka, D.; Gromadzka-Ostrowska, J.; Żyła, E.; Harasym, J.; Oczkowski, M. Selected Physiological Activities and Health Promoting Properties of Cereal Beta-Glucans. A Review. J. Anim. Feed Sci. 2017, 26, 183-191. [CrossRef]

64. Clarke, L.; Sweeney, T.; Curley, E.; Duffy, S.; Rajauria, G.; O’Doherty, J. The Variation in Chemical Composition of Barley Feed with or without Enzyme Supplementation Influences Nutrient Digestibility and Subsequently Affects Performance in Piglets. J. Anim. Physiol. Anim. Nutr. 2018, 102, 799-809. [CrossRef] [PubMed]

65. Adebowale, T.O.; Yao, K.; Oso, A.O. Major Cereal Carbohydrates in Relation to Intestinal Health of Monogastric Animals: A Review. Anim. Nutr. 2019, 5, 331-339. [CrossRef]

66. Ewaschuk, J.B.; Johnson, I.R.; Madsen, K.L.; Vasanthan, T.; Ball, R.; Field, C.J. Barley-Derived $\beta$-Glucans Increases Gut Permeability, Ex Vivo Epithelial Cell Binding to E. coli, and Naïve T-Cell Proportions in Weanling Pigs1,2. J. Anim. Sci. 2012, 90, $2652-2662$. [CrossRef]

67. Laroche, C.; Michaud, P. New Developments and Prospective Applications for $\beta(1,3)$ Glucans. Recent Pat. Biotechnol. 2007, 1, 59-73. [CrossRef] [PubMed]

68. Yan, J.-K.; Wang, W.-Q.; Wu, J.-Y. Recent Advances in Cordyceps Sinensis Polysaccharides: Mycelial Fermentation, Isolation, Structure, and Bioactivities: A Review. J. Funct. Foods 2014, 6, 33-47. [CrossRef]

69. Kim, Y.-W.; Kim, K.-H.; Choi, H.-J.; Lee, D.-S. Anti-Diabetic Activity of $\beta$-Glucans and Their Enzymatically Hydrolyzed Oligosaccharides from Agaricus Blazei. Biotechnol. Lett. 2005, 27, 483-487. [CrossRef] [PubMed]

70. Baeva, E.; Bleha, R.; Lavrova, E.; Sushytskyi, L.; Čopíková, J.; Jablonsky, I.; Klouček, P.; Synytsya, A. Polysaccharides from Basidiocarps of Cultivating Mushroom Pleurotus Ostreatus: Isolation and Structural Characterization. Molecules 2019, 24, 2740. [CrossRef] 
71. Ashraf Khan, A.; Gani, A.; Masoodi, F.A.; Mushtaq, U.; Silotry Naik, A. Structural, Rheological, Antioxidant, and Functional Properties of $\beta$-Glucan Extracted from Edible Mushrooms Agaricus Bisporus, Pleurotus Ostreatus and Coprinus Attrimentarius. Bioact. Carbohydr. Diet. Fibre 2017, 11, 67-74. [CrossRef]

72. Liu, J.; Sun, Y.; Yu, H.; Zhang, C.; Yue, L.; Yang, X.; Wang, L.; Liu, J. Purification and Identification of One Glucan from Golden Oyster Mushroom (Pleurotus Citrinopileatus (Fr.) Singer). Carbohydr. Polym. 2012, 87, 348-352. [CrossRef]

73. Santos-Neves, J.C.; Pereira, M.I.; Carbonero, E.R.; Gracher, A.H.P.; Alquini, G.; Gorin, P.A.J.; Sassaki, G.L.; Iacomini, M. A Novel Branched A $\beta$-Glucan Isolated from the Basidiocarps of the Edible Mushroom Pleurotus Florida. Carbohydr. Polym. 2008, 73, 309-314. [CrossRef]

74. Kao, P.F.; Wang, S.H.; Hung, W.T.; Liao, Y.H.; Lin, C.M.; Yang, W.B. Structural Characterization and Antioxidative Activity of Low-Molecular-Weights Beta-1,3-Glucan from the Residue of Extracted Ganoderma Lucidum Fruiting Bodies. J. Biomed. Biotechnol. 2012, 2012, 673764. [CrossRef]

75. Li, J.; Cai, C.; Zheng, M.; Hao, J.; Wang, Y.; Hu, M.; Fan, L.; Yu, G. Alkaline Extraction, Structural Characterization, and Bioactivities of $(1 \rightarrow 6)-\beta$-D-Glucan from Lentinus Edodes. Molecules 2019, 24, 1610. [CrossRef]

76. Morales, D.; Smiderle, F.R.; Villalva, M.; Abreu, H.; Rico, C.; Santoyo, S.; Iacomini, M.; Soler-Rivas, C. Testing the Effect of Combining Innovative Extraction Technologies on the Biological Activities of Obtained $\beta$-Glucan-Enriched Fractions from Lentinula Edodes. J. Funct. Foods 2019, 60, 103446. [CrossRef]

77. Umaña, M.; Turchiuli, C.; Rosselló, C.; Simal, S. Addition of a Mushroom By-Product in Oil-in-Water Emulsions for the Microencapsulation of Sunflower Oil by Spray Drying. Food Chem. 2021, 343, 128429. [CrossRef]

78. Freitas, I.S.; de Mendonça, M.O.; Freitas, I.S.; de Almeida Neto, O.B.; Ferreira, D.G.; Salgado, H.R.; Jesus Paula, D.A.D. Farinha Do Cogumelo Agaricus Blazei Como Aditivo Funcional Na Alimentação de Galinhas Poedeiras. Rev. Bras. Saúde Produção Anim. 2019, 20, e0612019. [CrossRef]

79. Chang, C.-S.; Huang, S.-L.; Chen, S.; Chen, S.-N. Innate Immune Responses and Efficacy of Using Mushroom Beta-Glucan Mixture (MBG) on Orange-Spotted Grouper, Epinephelus Coioides, Aquaculture. Fish Shellfish Immunol. 2013, 35, 115-125. [CrossRef] [PubMed]

80. Hozova, B.; Kuniak, E.; Kelemenova, B. Application of Beta-D-Glucans Isolated from Mushrooms Pleurotus Ostreatus (Pleuran) and Lentinus Edodes (Lentinan) for Increasing the Bioactivity of Yoghurts. Czech J. Food Sci. 2004, 22, 204-214. [CrossRef]

81. Brennan, M.A.; Derbyshire, E.; Tiwari, B.K.; Brennan, C.S. Integration of $\beta$-Glucan Fibre Rich Fractions from Barley and Mushrooms to Form Healthy Extruded Snacks. Plant Foods Hum. Nutr. 2013, 68, 78-82. [CrossRef] [PubMed]

82. Kim, J.; Lee, S.; Bae, I.Y.; Park, H.-G.; Lee, H.; Lee, S. (1-3)(1-6)- $\beta$-Glucan-Enriched Materials from Lentinus Edodes Mushroom as a High-Fibre and Low-Calorie Flour Substitute for Baked Foods. J. Sci. Food Agric. 2011, 91, 1915-1919. [CrossRef]

83. Djordjevic, B.; Škugor, S.; Jørgensen, S.M.; Øverland, M.; Mydland, L.T.; Krasnov, A. Modulation of Splenic Immune Responses to Bacterial Lipopolysaccharide in Rainbow Trout (Oncorhynchus Mykiss) Fed Lentinan, a Beta-Glucan from Mushroom Lentinula Edodes. Fish Shellfish Immunol. 2009, 26, 201-209. [CrossRef] [PubMed]

84. García-Rojas, D.; Meneses, M.; Martínez-Carrera, D.; Figueroa-Cárdenas, J.; Sánchez-Medina, M.; Bonilla-Quintero, M.; PetlacalcoSánchez, B.; Martínez-Gutiérrez, G.; Pérez-Herrera, A. Effect of Pleurotus Agaves Mushroom Addition on the Physicochemical and Sensory Properties of Blue Maize Tortillas Produced with Traditional and Ecological Nixtamalization. Food Funct. 2020, 11, 8768-8779. [CrossRef] [PubMed]

85. Pappa, E.; Kondyli, E.; MacNaughtan, W.; Kakouri, A.; Nesseris, K.; Israilides, C. Quality and Sensory Properties of Reduced Fat Yoghurt Made with Addition of $\beta$-Glucans. Food Nutr. Sci. 2018, 9, 390-402. [CrossRef]

86. Maiti, T.K.; Mal, B.C.; Joardar, S.N.; Kamilya, D. Effects of a Glucan from the Edible Mushroom (Pleurotus Florida) as an Immunostimulant in Farmed Indian Major Carp (Catla Catla). Isr. J. Aquac.-Bamidgeh 2008, 60, 20471.

87. Wan Ishak, W.R.; Solihah, M.A.; Aishah, M.; Fakurudin, N.A.; Mohsin, S.S.J. Colour, Textural Properties, Cooking Characteristics and Fibre Content of Chicken Patty Added with Oyster Mushroom (Pleurotus Sajor-Caju). Int. Food Res. J. 2011, 18, 612-618.

88. Kondyli, E.; Pappa, E.C.; Kremmyda, A.; Arapoglou, D.; Metafa, M.; Eliopoulos, C.; Israilides, C. Manufacture of Reduced Fat White-Brined Cheese with the Addition of $\beta$-Glucans Biobased Polysaccharides as Textural Properties Improvements. Polymers 2020, 12, 2647. [CrossRef] [PubMed]

89. Aida, F.M.N.A.; Shuhaimi, M.; Yazid, M.; Maaruf, A.G. Mushroom as a Potential Source of Prebiotics: A Review. Trends Food Sci. Technol. 2009, 20, 567-575. [CrossRef]

90. Katya, K.; Yun, Y.-H.; Park, G.; Lee, J.-Y.; Yoo, G.; Bai, S. Evaluation of the Efficacy of Fermented By-Product of Mushroom, Pleurotus Ostreatus, as a Fish Meal Replacer in Juvenile Amur Catfish, Silurus Asotus: Effects on Growth, Serological Characteristics and Immune Responses. Asian-Australas. J. Anim. Sci. 2014, 27, 1478-1486. [CrossRef] [PubMed]

91. FDA Food Labeling: Health Claims; Oats and Coronary Heart Disease. Fed. Regist. 1997, 62, 3584-3601.

92. Avramia, I.; Amariei, S. Spent Brewer's Yeast as a Source of Insoluble $\beta$-Glucans. Int. J. Mol. Sci. 2021, 22, 825. [CrossRef] [PubMed]

93. Shalaby, M.; Abo-Rya, M.; Motawei, A.-Z. Effect of baking process on $\beta$-glucan content in whole barley balady bread. J. Food Dairy Sci. 2014, 5, 481-490. [CrossRef]

94. Martins, Z.; Erben, M.; Gallardo, A.; Silva, R.; Barbosa, I.; Castro Pinho, O.; Ferreira, I.M.P.L.V.O. Effect of Spent Yeast Fortification on Physical Parameters, Volatiles and Sensorial Characteristics of Home-Made Bread. Int. J. Food Sci. Technol. 2015, 50, 1855-1863. [CrossRef] 
95. Martins, Z.E.; Pinho, O.; Ferreira, I.M.P.L.V.O. Impact of New Ingredients Obtained from Brewer's Spent Yeast on Bread Characteristics. J. Food Sci. Technol. 2018, 55, 1966-1971. [CrossRef]

96. Suwannarong, S.; Wongsagonsup, R.; Suphantharika, M. Effect of Spent Brewer's Yeast $\beta$-D-Glucan on Properties of Wheat Flour Dough and Bread during Chilled Storage. Int. J. Biol. Macromol. 2020, 156, 381-393. [CrossRef]

97. Bacha, U.; Nasir, M.; Iqbal, S.; Anjum, A.A. Influence of Yeast $\beta$-Glucan on Cookies Sensory Characteristics and Bioactivities. J. Chem. 2018, 2018, 1295184. [CrossRef]

98. Piotrowska, A.; Waszkiewicz-Robak, B.; Świderski, F. Possibility of Beta -Glucan from Spent Brewer's Yeast Addition to Yoghurts. Pol. J. Food Nutr. 2009, 59, 299-302.

99. Mejri, W.; Bornaz, S.; Sahli, A. Formulation of Non-Fat Yogurt with $\beta$-Glucan from Spent Brewer's Yeast. J. Hyg. Eng. Des. 2014, 8 , 163-173.

100. Raikos, V.; Grant, S.; Hayes, H.; Ranawana, V. Use of $\beta$-Glucan from Spent Brewer's Yeast as a Thickener in Skimmed Yogurt: Physicochemical, Textural, and Structural Properties Related to Sensory Perception. J. Dairy Sci. 2018, 101, 5821-5831. [CrossRef] [PubMed]

101. Worrasinchai, S.; Suphantharika, M.; Pinjai, S.; Jamnong, P. $\beta$-Glucan Prepared from Spent Brewer's Yeast as a Fat Replacer in Mayonnaise. Food Hydrocoll. 2006, 20, 68-78. [CrossRef]

102. MARINESCU, G.; STOICESCU, A.; Patrascu, L. The Preparation of Mayonnaise Containing Spent Brewer's Yeast $\beta$ - Glucan as a Fat Replacer. Romanian Biotechnol. Lett. 2011, 16, 6017-6025.

103. Apostu, P.M.; Mihociu, T.E.; Nicolau, A.I. Technological and Sensorial Role of Yeast $\beta$-Glucan in Meat Batter Reformulations. J. Food Sci. Technol. 2017, 54, 2653-2660. [CrossRef]

104. Gadde, U.; Kim, W.H.; Oh, S.T.; Lillehoj, H.S. Alternatives to Antibiotics for Maximizing Growth Performance and Feed Efficiency in Poultry: A Review. Anim. Health Res. Rev. 2017, 18, 26-45. [CrossRef]

105. Cho, J.H.; Zhang, Z.F.; Kim, I.H. Effects of Single or Combined Dietary Supplementation of $\beta$-Glucan and Kefir on Growth Performance, Blood Characteristics and Meat Quality in Broilers. Br. Poult. Sci. 2013, 54, 216-221. [CrossRef]

106. Ding, B.; Zheng, J.; Wang, X.; Zhang, L.; Sun, D.; Xing, Q.; Pirone, A.; Fronte, B. Effects of Dietary Yeast Beta-1,3-1,6-Glucan on Growth Performance, Intestinal Morphology and Chosen Immunity Parameters Changes in Haidong Chicks. Asian-Australas. J. Anim. Sci. 2019, 32, 1558. [CrossRef]

107. Rajapakse, R.; Buddhika, M.; Nagataki, M.; Nomura, H.; Watanabe, Y.; Ikeue, Y.; Agatsuma, T. Effect of Sophy.BETA.-Glucan on Immunity and Growth Performance in Broiler Chicken. J. Vet. Med. Sci. Jpn. Soc. Vet. Sci. 2010, 72, 1629-1632. [CrossRef] [PubMed]

108. Tian, X.; Shao, Y.; Wang, Z.; Guo, Y. Effects of Dietary Yeast $\beta$-Glucans Supplementation on Growth Performance, Gut Morphology, Intestinal Clostridium Perfringens Population and Immune Response of Broiler Chickens Challenged with Necrotic Enteritis. Anim. Feed Sci. Technol. 2016, 215, 144-155. [CrossRef]

109. Sánchez-Martínez, J.; Rábago, J.; Vazquez, M.; Pérez-Castañeda, R.; Blanco, Z.; Benavides-González, F. Effect of $\beta$ Glucan Dietary Levels on Immune Response and Hematology of Channel Catfish Ictalurus Punctatus Juveniles. Lat. Am. J. Aquat. Res. 2017, 45, 690-698. [CrossRef]

110. Gopalakannan, A.; Arul, V. Enhancement of the Innate Immune System and Disease-resistant Activity in Cyprinus Carpio by Oral Administration of B-glucan and Whole Cell Yeast. Aquac. Res. 2009, 41, 884-892. [CrossRef]

111. Luo, J.; Zeng, D.; Cheng, L.; Mao, X.; Yu, J.; Yu, B.; Chen, D. Dietary $\beta$-Glucan Supplementation Improves Growth Performance, Carcass Traits and Meat Quality of Finishing Pigs. Anim. Nutr. 2019, 5, 380-385. [CrossRef] [PubMed]

112. Wu, C.; Xu, Q.; Wang, R.; Peng, X.; Qing, L.; Hu, L.; Liu, Y.; Fang, Z.; Lin, Y.; xu, S.; et al. Effects of Dietary $\beta$-Glucan Supplementation on Growth Performance, Immunological and Metabolic Parameters of Weaned Pigs Challenged with Escherichia Coli Lipopolysaccharide. Food Funct. 2018, 9, 3338-3343. [CrossRef]

113. Santurio, J.M.; Alves, S.H.; Pereira, D.I.B.; Vetvicka, V.; Oliveira, C. Effect of Yeast Purified Beta-Glucan in Experimental Treatment of Pythiosis in Rabbits. Int. Clin. Pathol. J. 2020, 8, 14-20.

114. Zabek, K.; Milewski, S.; Wójcik, R.; Siwicki, A.K. Effect of $\beta-1,3 / 1$, 6-D-Glucan in Diet on Productivity and Humoral and Cellular Defense Mechanisms in Sheep. Acta Vet. Brno 2013, 82, 141-146. [CrossRef]

115. Aboushanab, S.; Vyrova, D.; Selezneva, I.; Ibrahim, M. The Potential Use of $\beta$-Glucan in the Industry, Medicine and Cosmetics. AIP Conf. Proc. 2019, 2174. [CrossRef]

116. Jayachandran, M.; Chen, J.; Chung, S.S.M.; Xu, B. A Critical Review on the Impacts of $\beta$-Glucans on Gut Microbiota and Human Health. J. Nutr. Biochem. 2018, 61, 101-110. [CrossRef]

117. Delatte, S.J.; Evans, J.; Hebra, A.; Adamson, W.; Othersen, H.B.; Tagge, E.P. Effectiveness of Beta-Glucan Collagen for Treatment of Partial-Thickness Burns in Children. J. Pediatr. Surg. 2001, 36, 113-118. [CrossRef] 